\title{
Further contributions to the early Miocene forest vegetation of the Galatian Volcanic Province, Turkey
}

\author{
N. Neslihan Acarca Bayam, Ünal Akkemik, Imogen Poole, and Ferdi Akarsu
}

\begin{abstract}
Ten new petrified forest sites have been discovered on the Galatian Volcanic Province (GVP). The silicified woods, preserved in the lower Miocene Hançili and Pazar formations, represent a diverse plant assemblage that grew across western and central GVP during the Burdigalian, ca. 20-17 Ma. The assemblage comprises a total of 233 petrified woods collected from the 10 sites in and around Ankara (Beypazarı, Çamlıdere, Kızılcahamam) and Bolu (Kıbrısçık). Taxonomic identifications of the fossil wood floras suggest four distinct vegetational associations can be recognized on the GVP: (1) swamp associations of Glyptostrobus Endlicher, Sequoia Endlicher and Taxodium Richard; (2) riparian forest comprising palms, Salix L., Liquidambar L. and Quercus L. section Ilex; (3) mesic-xeric woodland comprising Acer L., Quercus L., Pinus L. and Juniperus L.; and (4) mixed coniferous-angiosperm forest comprising Picea A. Dietrich, Cedrus Trew., Pinus, Juniperus L. and Podocarpus L'Herit (ex Pers.) alongside. These associations support the idea that the landscape was varied and the climate warm and frost free.
\end{abstract}

N. Neslihan Acarca Bayam. Çapa Science College, 34104 Çapa-İstanbul, Turkey.

nneslihan.acarca@gmail.com

Ünal Akkemik. İstanbul University, Faculty of Forestry, Department of Forest Botany, 34473 Bahçeköy-

Sarıyer, İstanbul, Turkey. uakkemik@istanbul.edu.tr

Imogen Poole. Aberdeen, United Kingdom. poole.imogen@gmail.com

Ferdi Akarsu. İstanbul University, Faculty of Forestry, Department of Forest Botany, 34473 Bahçeköy-

Sarıyer, İstanbul, Turkey. fakarsu@istanbul.edu.tr

Keywords: Miocene; silicified wood; petrified forest; wood identification; Galatian Volcanic Province; Köroglu Volcanics, Turkey

Submitted: 4 September 2017 Accepted: 2 November 2018

Acarca Bayam, N. Neslihan, Akkemik, Ünal, Poole, Imogen, and Akarsu, Ferdi 2018. Further contributions to the early Miocene forest vegetation of the Galatian Volcanic Province, Turkey. Palaeontologia Electronica 21.3.40A 1-42. https://doi.org/10.26879/816 palaeo-electronica.org/content/2018/2353-trees-of-gvp-in-miocene

Copyright: November 2018 Paleontological Society.

This is an open access article distributed under the terms of Attribution-NonCommercial-ShareAlike 4.0 International (CC BY-NC-SA 4.0), which permits users to copy and redistribute the material in any medium or format, provided it is not used for commercial purposes and the original author and source are credited, with indications if any changes are made.

creativecommons.org/licenses/by-nc-sa/4.0/ 


\section{INTRODUCTION}

The Galatean Volcanic Province (GVP) (or Köroglu Volcanics) is a major Neogene volcanic belt covering an area of approximately $12,800 \mathrm{~km}^{2}$ (Koçyiğit et al., 2003) and located in central Anatolia in the northwestern part of Turkey (Toprak et al., 1996). The GVP and three other volcanic provinces in western, central and eastern Anatolia together form the four main Neogene and Quaternary volcanic fields in Turkey (Kazancı, 2012) that evolved as a consequence of the tectonic collision between the African Plate and the Eurasian Plate (Wilson et al., 1997; Tankut et al., 1998; Rögl, 1999; Koçyiğit et al., 2003). Most of the volcanic products of the GVP belong to the eruptions from nine eruption centers (Figure 1) so far identified, which grade from basalts to andesite and rhyolites (Kazancı, 2012). Rocks were deposited during three major volcanic phases: (1) late CampanianLutetian subductional phase; (2) post-Lutetian collisional phase; and (3) Oligocene-Miocene post-collisional phase (Koçyiğit et al., 2003).

Keller et al. (1992), Wilson et al. (1997) and Adıyaman et al. (2001) suggest that during the Oligocene-Miocene volcanic phase three episodes of volcanism took place across the GVP: the first around 22-19 Ma, followed by a second episode between 18-17 Ma and a third episode of volcanism during the late Miocene (10-9 Ma). Potassium-argon dating of volcanic rocks determined that the major phase of volcanic activity took place

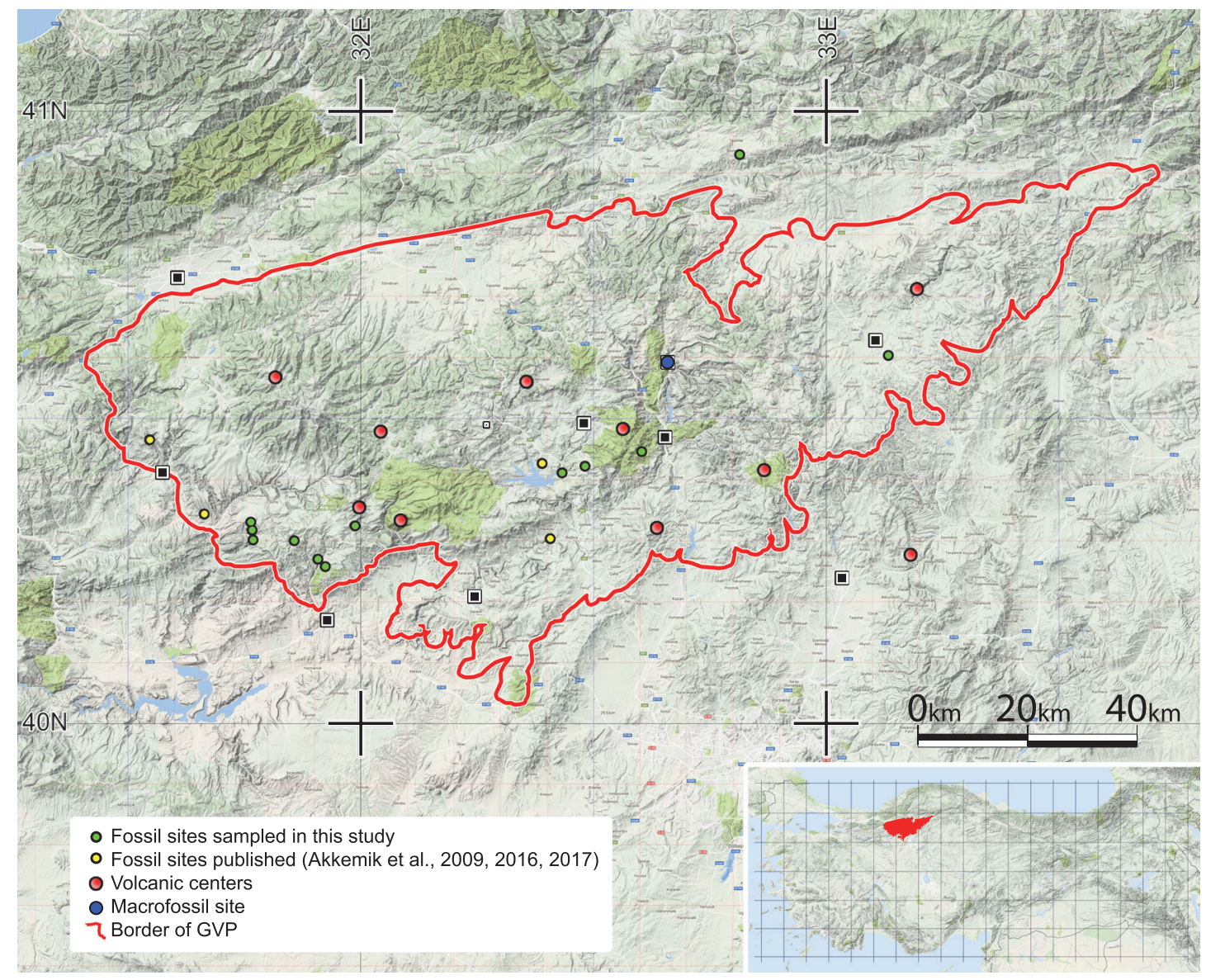

FIGURE 1. Map showing the area covered by the Galatian Volcanic Province (GVP) (or Köroglu Volcanics). Sites discussed in this work are marked by green circles: ELM, Elmali Village; SOG, Soguksu National Park; BUG, Bugralar Village; INO, Inozu Valley South Side; INL, Inozu Valley North Side; KAR, Karasar Village; MEN, Menceler Plateau; KIR, Kiraluc Sitenear Nuhhoca Village; AGU, Asagiguney Village; KUZ, Kuzca Village. Yellow circles (PEL, Pelitcik Village; GUD, Gudul; HOC, Hoçaş Village; KOZ, Kozyaka Village) indicate those sites discussed in Akkemik et al. (2009, 2016, 2017). The sites located in the western part (INO, INL, KAR, MEN, KIR, AGU, KUZ, HOC and KUZ) are from early-middle Burdigalian and Hancili Formation (Altun et al., 2002; Akbaş et al., 2002); the sites in the central part (GUD, BUG, ELM, PEL and SOG) are from middle-late Burdigalian and Pazar Formation (Kazancı, 2012; Sen et al., 2017). 


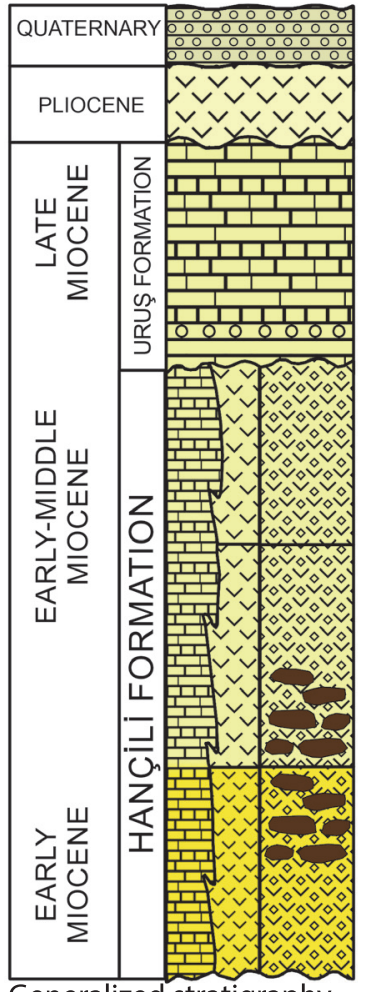

Generalized stratigraphy of west GVP

(KOZ, HOC, KUZ, AGU, KIR,

MEN, INL, INO, KAR)

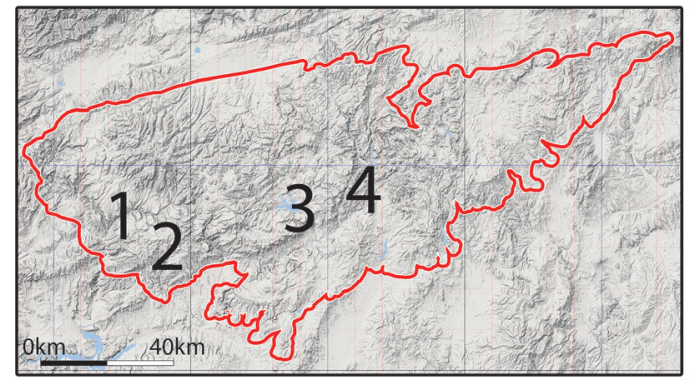

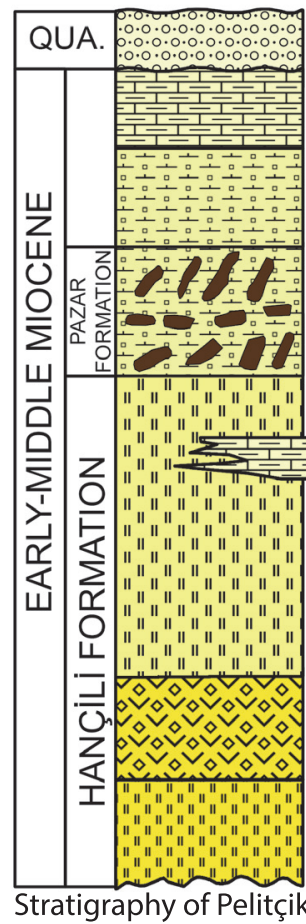

(PEL, ELM, BUG)

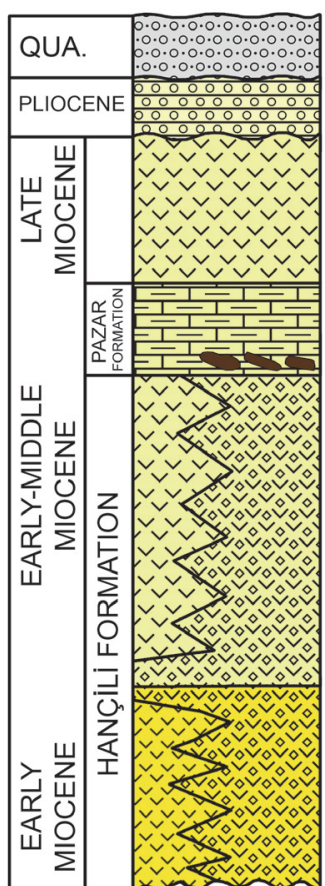

Stratigraphy of Kızılcahamam (SOG)

FIGURE 2. Stratigraphic columns of the GVP showing the fossils (dark symbols) originating from the Hançili Formation of the western part (1-2) (Akbaş et al., 2002; Altun et al., 2002) and from within the pyroclastic layers of the Pazar Formation in the central part of the GVP at Çamlıdere-Pelitcik (3) and Kızılcahamam (4). Columns redrawn from figure 3 for Kızılcahamam and figure 6 for Pelitcik of Kazancı (2012) and figure 2 of Şen et al. (2017).

during the early Miocene (20-17 Ma; Wilson et al., 1997), which resulted in the accumulation of thick volcanic and volcaniclastic rocks intercalated with continental sedimentary rock (Toprak et al., 1996).

The fossil wood material from the western part of the GVP originated from the lower part of the early to early-middle Miocene Hançili Formation (Akbaş et al., 2002; Altun et al., 2002) (Figure 2), a sequence of conglomerates, coals and organic-rich shales and claystones reflecting deposition in lacustrine and coastal environments under warm, humid climatic conditions (Vosoughi Moradi et al.,
2016). Radiometric dating of the early Miocene volcanic basalts across the western part of the GVP have been undertaken by several workers: Toprak et al. (1996), summarizing Türkecan et al. (1991) and Keller et al. (1992), give the age of the exposed volcanoclastic rocks found in the southwestern part of the Kartalkaya-Köroglu Complex near Seben (Figure 1) in the western part of the GVP as ranging from $24.83 \pm 2.01$ to $21.79 \pm 4.93$ Ma. Subsequently Akkemik et al. (2016) undertook radiometric dating of volcanic rocks taken from around the silicified wood samples that originated 
from the Seben-Hoçaş Fossil Forest (Bolu Province, Figure 1), just west of the sites sampled in this study. These returned an age of $18.2 \pm 0.8 \mathrm{Ma}$ (early-middle Burdigalian). These data suggest an age range of ca. 24.8-18 Ma (Aquitanian-Burdigalian) for the fossil woods found in the western part of the GVP.

The fossils found in the central part of the GVP were recovered from the Pazar Formation (Figure 2), a sequence of argillaceous limestones, marl and claystones with locally cherty limestone, sandstone and tuff, and occasional thin coal seams (Süzen and Türkmenoglu, 2000; Yavuz-Işık and Demirci, 2009; Sen et al., 2017). Tatlı (1975) stated that Pazar Formation was formed in lake and swamp environments. Sen et al. (2017) suggested that the Pazar Formation was deposited during the early and early middle Miocene. The fossils originated from the basal layers of the Pazar Formation at Kizilcahamam, but were more evenly dispersed throughout the formation at the Pelitcik sites (Figure 2). Representative basalt samples from the volcanic layers covering the central part of the GVP, near the towns of Özmus and Güdül (Figure 1), were analyzed by Wilson et al. (1997) and returned ages of $18.2 \pm 0.5 \mathrm{Ma}$ and $18.8 \pm 0.6 \mathrm{Ma}$ (both middle Burdigalian), respectively. Further basalt samples from Güvem and Çamlıdere (Figure 1) returned an age of middle to late Burdigalian (18.2 [ \pm 0.5$]-16.9[ \pm 0.5] \mathrm{Ma}$, respectively) (Table 1) (Tankut et al., 1995; Wilson et al., 1997). Based on this evidence we consider the age of the fossils preserved in the same volcanic rocks covering the central part of the GVP to be middle to late Burdigalian and thus coeval or slightly younger that those fossils found in the west. Given that the two regions are interpreted to have formed from the same volcanic processes, and that there exists a degree of overlap in the ages of these two regions, until further dating is undertaken we consider the material found in the western and the central region of the GVP to be relatively contemporaneous.

The GVP is one of the most important areas for fossil forest preservation in Turkey (Akkemik et al., 2016 and references cited therein) at a time when particularly warm conditions favoured the growth of rich forest vegetation across the Northern Hemisphere (Mai, 1995; Zachos et al., 2008; Denk et al., 2011, 2017a, 2017b, 2017c). Fossilized animal remains alongside petrified wood, leaf, fruit and cones are commonly found in the lower Miocene volcano-sedimentary units in the central part of the GVP (Kasaplıgil 1977; Dernbach et al.,
1996; Akkemik et al., 2009, 2016, 2017; Denk et al., 2017b). Here evidence supports a mixed conifer-deciduous and evergreen angiosperm early Miocene vegetation growing in the KizilcahamamCamlidere-Güvem area (Figure 1), with Sequoia, Taxodium Rich., Quercus section Ilex, Acer, Salix, Populus, Ulmus, Zelkova, Alnus Mill. Betula L. Fabaceae, Engelhardioideae (Akkemik et al., 2009; Dernbach et al., 1996; Kasaplıgil, 1977; Denk et al., 2017b). To the south, near Güdül (Figure 1), Kasapligil (1977) and Akkemik et al. (2017) identified leaves and woods belonging to Glyptostrobus and Glyptostroboxylon Conwentz and concluded this taxon formed a main constituent of a prevailing swamp forest vegetation. Further north, near Pelitçik (Figure 1), a Sequoia type wood along with wood of Taxodium were identified as representative forest trees (Akkemik et al., 2009). The 'Sequoia type' wood is distinct in that it includes anatomical features of Sequoia, Sequoiadendron J. Buchholz and Metasequoia Miki and thus cannot be identified as belonging to either one of these modern genera; with better preserved samples a closer identification may be possible.

In the western part of the GVP, Akkemik et al. (2016) also described wood samples recovered from two early Miocene sites: one near the village of Hoçaş and the second near the village of Kozyaka (Figure 1). Both sites lie at an altitude of $\sim 900 \mathrm{~m}$ close to the town of Seben (Figure 1) in the province of Bolu, and together are referred to as the Seben Fossil Forest. The Hoçaş site had preserved both in situ and in situ samples that include Palmae, Salix L., Liquidambar, Quercus section Ilex and Juniperus, Acer, Cedrus and Picea. The Kozyaka site also yielded samples of Acer, Quercus L. (Ilex type), Cedrus, along with Salix/Populus L., Ulmus L., and Pinus (Akkemik et al., 2016).

Although these studies have provided an indication of the local vegetation that grew across the western and central parts of the GVP during the early Miocene, ideas pertaining to the flora that grew here are still limited. The discovery of new petrified wood sites and the subsequent analyses of the wood samples discussed in context of the vegetational hypotheses presented in previous publications, forms the basis of this work and helps further understanding of the flora and ecological dynamics that prevailed across Anatolia during the Miocene.

\section{MATERIAL AND METHODS}

Ten new petrified forest sites within GVP have been identified (Figure 1, Table 1). From these 
TABLE 1. Summary of the range of dimensions of the samples and the total number of samples collected from the 10 new fossiliferous sites along with site details and observations on the autochthonous/allochthonous nature of the material collected.

\begin{tabular}{|c|c|c|c|c|c|c|c|c|c|}
\hline Locality & Code & Longitude & Latitude & $\begin{array}{l}\text { Altitude } \\
\text { (m) }\end{array}$ & $\begin{array}{c}\text { Total } \\
\text { number } \\
\text { collected }\end{array}$ & $\begin{array}{l}\text { Length } \\
\text { (cm) }\end{array}$ & $\begin{array}{l}\text { Radial } \\
\text { (cm) }\end{array}$ & $\begin{array}{l}\text { Tangential } \\
\text { (cm) }\end{array}$ & Observation \\
\hline \multicolumn{10}{|c|}{ Western GVP (Hancili Formation) } \\
\hline $\begin{array}{l}\text { Bolu-Kıbrısçık- } \\
\text { Kuzca- } \\
\text { Alanhümmet } \\
\text { Villages }\end{array}$ & KUZ & E3145'45.7554" & N40¹9'49.6914" & 1272 & 22 & $2.5-25$ & $1-9$ & $2-11$ & $\begin{array}{l}\text { Sample KUZ20 } \\
\text { allochthonous; all } \\
\text { others ex-situ } \\
\text { authochthonous }\end{array}$ \\
\hline $\begin{array}{l}\text { Beypazarı- } \\
\text { Nuhhoca } \\
\text { Village (Kıraluç }\end{array}$ & $\mathrm{KIR}$ & E31ํ5'53.4234" & N4018'3.528" & 1268 & 73 & $4-22$ & $1.5-10$ & $1-16$ & $\begin{array}{l}\text { ex-situ } \\
\text { authochthonous }\end{array}$ \\
\hline $\begin{array}{l}\text { Beypazarı- } \\
\text { Aşağıgüney } \\
\text { Village }\end{array}$ & AGU & E31ํ5'54.7554" & N4019' 6.6714" & $1141 / 1250$ & 28 & $5-24$ & $3-9.5$ & $2-10$ & $\begin{array}{l}13 \text { samples } \\
\text { allochthonous; all } \\
\text { others ex-situ } \\
\text { authochthonous }\end{array}$ \\
\hline $\begin{array}{l}\text { Beypazarı- } \\
\text { Karaşar Village }\end{array}$ & KAR & E31 $58^{\circ} 53.2194^{\prime \prime}$ & N40' 19' 20.6034" & 1370 & 1 & 11 & 6.5 & 6.5 & $\begin{array}{l}\text { ex-situ } \\
\text { authochthonous }\end{array}$ \\
\hline $\begin{array}{l}\text { Beypazarı- } \\
\text { Mençeler Valley }\end{array}$ & MEN & $\begin{array}{l}\text { E3151'1.9794"/ } \\
\text { E31ํ51'1.9794" }\end{array}$ & $\begin{array}{c}\text { N4017'33.1794"/ } \\
\text { N4017'31.776" }\end{array}$ & $1340 / 1374$ & 34 & 5-20.5 & $6-12$ & $1-11$ & $\begin{array}{l}\text { ex-situ } \\
\text { authochthonous }\end{array}$ \\
\hline $\begin{array}{l}\text { Beypazarı- } \\
\text { Inozu Valley } \\
\text { (north side) }\end{array}$ & $\mathrm{INL}$ & $\mathrm{E} 31^{\circ} 54^{\prime} 55.26^{\prime \prime}$ & N4015'24.8754" & 1117 & 10 & $7-28$ & $2-8.5$ & $1.5-25$ & $\begin{array}{l}\text { ex-situ } \\
\text { authochthonous }\end{array}$ \\
\hline $\begin{array}{l}\text { Beypazarı- } \\
\text { Inozu Valley }\end{array}$ & INO & E315ㄴ'34.596" & N4015'43.308" & 998 & 11 & $3-24$ & $2.5-8$ & $1.5-14$ & $\begin{array}{l}\text { ex-situ } \\
\text { authochthonous }\end{array}$ \\
\hline \multicolumn{10}{|c|}{ Central GVP (Pazar Formation) } \\
\hline Çamlıdere- & BUG & E32²6'3.2994" & N402'ㄴ․ $34.48 "$ & 1005 & 30 & $4-21$ & $2-12.5$ & $1-9$ & ex-situ honous \\
\hline $\begin{array}{l}\text { Çamlıdere- } \\
\text { Elmalı Village }\end{array}$ & ELM & E32²8'31.692" & $\mathrm{N} 40^{\circ} 25^{\prime} 0.804^{\prime \prime}$ & 1233 & 18 & $3-19.5$ & $4-13.5$ & $1.5-8.5$ & $\begin{array}{l}\text { ex-situ } \\
\text { authochthonous }\end{array}$ \\
\hline $\begin{array}{l}\text { Kızılcahamam- } \\
\text { Soğuksu }\end{array}$ & SOG & E32³7'49.9404" & N4028'7.2948" & 1052 & 6 & $1-11$ & $2-8.5$ & $1-6$ & $\begin{array}{l}\text { ex-situ } \\
\text { authochthonous }\end{array}$ \\
\hline
\end{tabular}

sites a total of 233 silicified wood samples were collected ranging from 3 to $30 \mathrm{~cm}$ in length/height and 0.5 to $17 \mathrm{~cm}$ in diameter. The woods comprise both in situ stumps (Figure 3 ) decapitated by a volcanic eruption, but still in their life position (authochthonous), or relatively small pieces of in situ (allochthonous) material including those specimens from trees felled by volcanic activity and subsequently moved from the original growth position (Figure 4). Preservation is variable with some specimens showing good preservation, whilst others are poorly preserved. The in situ fossil wood specimens collected from the Çamlıdere-Elmalı Village site (ELM) were generally too badly preserved for any further analysis.

Each petrified wood sample is coded using the first three letters of the site name (Table 1) and numbered sequentially. Those samples found in situ are identified by ' $D$ ' following the site name identifier (and prefixing the sample number). Samples are deposited in the Wood Anatomy Laboratory of the Forest Botany Department, Faculty of Forestry at Istanbul University.

Sixty-two of the samples were thin sectioned along the three planes of section (transverse section, TS, radial longitudinal section, RLS, and tangential longitudinal section, TLS), and identified using transmitted light microscopy. Descriptions follow the terminology of the IAWA Committee (1989) for hardwood identification and IAWA Committee (2004) for softwood identification wherever possible. Measurements were taken and documented using guidelines recommended by the IAWA Committee $(1989,2004)$ (i.e., the mean fol- 

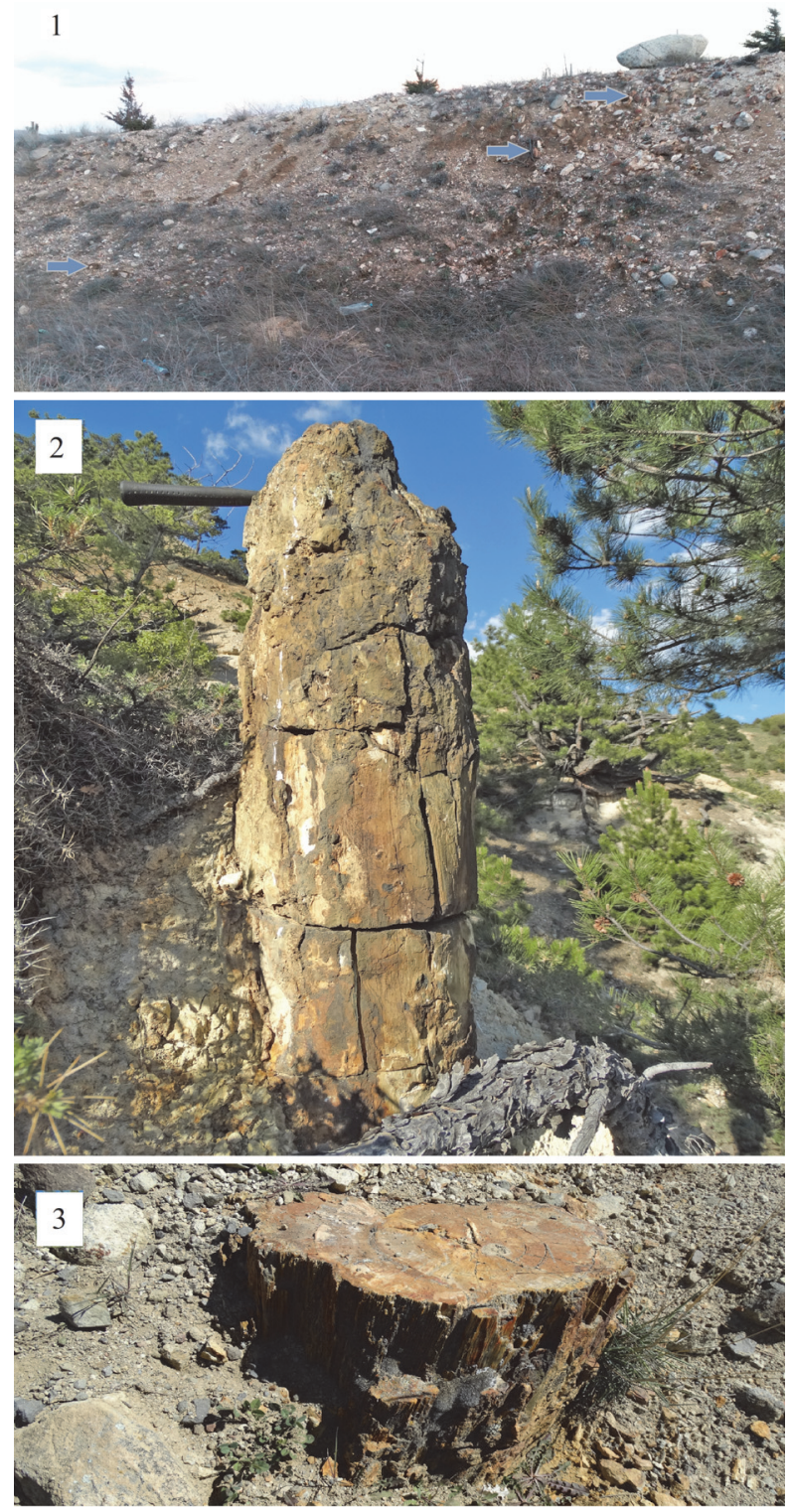

FIGURE 3. Examples of petrified wood specimens. 1, Example of small wood samples found at the Bugralar Fossil Site (BUG), from the central part of GVP, with an age of middle-late Burdigalian. 2, Petrified woods found in their life position in Asagiguney Site (AGU). 3, Material found in Kuzca Village (KUZ) in the west part of the GVP of early-middle Burdigalian age.

lowed by minimum and maximum measurements in parentheses). Identifications were made following reference to well-described extant wood, such as vouchered specimens housed in Forest Botany Department of Faculty of Forestry, University of Istanbul, comparisons with published literature (Jacquiot, 1955; Greguss, 1955, 1967; Barefoot and Hankins, 1982; Fahn et al., 1986; Schweingruber, 1990, 1993; Tidwell, 1998; Eliçin, 1977; Vassio

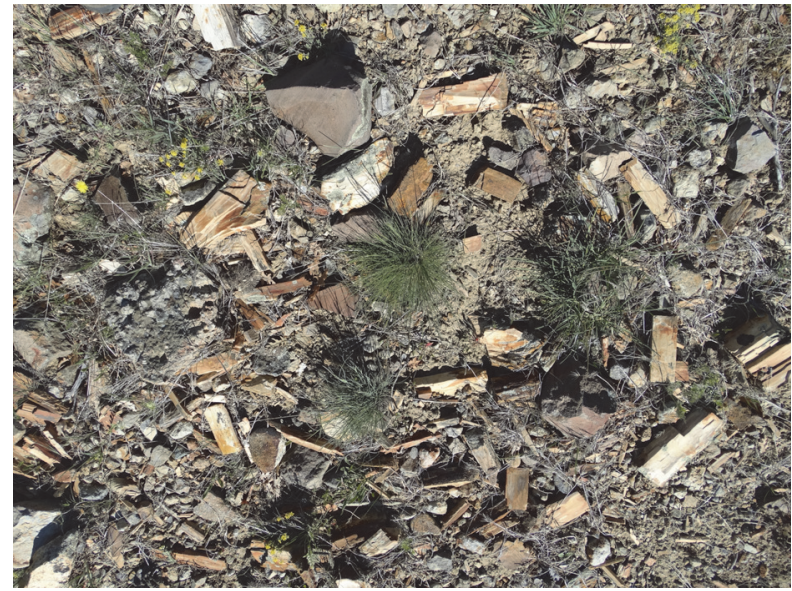

FIGURE 4. Example of allochthonous petrified woods from Kuzca Village (KUZ) in the Galatian Volcanic Province.

et al., 2008; Wheeler, 2011; Akkemik and Yaman, 2012; Uhl et al., 2014) and online databases such as InsideWood for angiosperm wood (http://insidewood.lib.nsc.edu).

\section{SYSTEMATIC PALAEOBOTANY}

A total of 14 different genera were identified from 10 fossil sites across the GVP. Seven of them were conifers, and the rest angiosperms. A summary of the wood characters of each taxon outlined below is based on all samples listed. Measurements for each individual sample are given in Appendices 1 and 2.

Family CUPRESSACEAE Rich. ex Bartling, 1830 Genus JUNIPERUS Linnaeus, 1753 Juniperus sp.

Material. AGU04, AGU05, AGU09, AGU11 (in situ); AGUD3, AGUD7, AGUD8, AGUD10 (in situ). Locality. Near to the village of BeypazarıAşağıgüney (AGU).

Description. Ex-situ and in-situ material with dimensions ranging from 4 to $16 \mathrm{~cm}$ in height/ length, and 2 to $8 \mathrm{~cm}$ in diameter.

Transverse section (TS). Growth ring widths $0.2-$ $1.5 \mathrm{~mm}$ with distinct boundaries. Transition from earlywood to latewood gradual with latewood tracheids forming a layer 1-2 rows deep; false rings common. Resin canals absent. Intercellular spaces obvious and occur throughout the wood. Tracheid tangential and radial diameters measure 15 (5-25) $\mu \mathrm{m}$ and 16 (3-28) $\mu \mathrm{m}$, respectively, in earlywood, and $9(2-17) \mu \mathrm{m}$ and $5(1-13) \mu \mathrm{m}$, respectively, in the latewood. Tracheid wall thickness measures 4 (1-9) $\mu \mathrm{m}$ (thin walled) in earlywood and $6(2-12)$ $\mu \mathrm{m}$ (thick walled) in latewood. Axial parenchyma is 
common, and both diffuse (in the transition from earlywood to latewood and within the latewood itself) and tangentially zonate (Figure 5).

Tangential longitudinal section (TLS). Rays exclusively uniseriate. Ray height is $2-5$ (max.12) cells or $45(9-226) \mu \mathrm{m}$; ray width is $8(4-18) \mu \mathrm{m}$ in width. Transverse end walls of axial parenchyma cells are clearly, or slightly, nodular (Figure 5). Tracheid pitting in tangential walls is common.

Radial longitudinal section (RLS). Rays homogeneous. Ray tracheids absent. End walls of ray parenchyma cells nodular and indentures are present. Nodular end walls present. Cross-field pitting is cupressoid with $3-5$ pits per cross-field. Tracheid pitting in radial walls of the earlywood is predominantly uniseriate (Figure 5).

Comments. The combination of wood features described here is consistent with that of Juniperus and are similar to those of the eight juniper species growing today in Turkey. All eight species grow across the whole of Anatolia with three of them, Juniperus excelsa M. Bieb., J. drupacea Labill. and J. oxycedrus L., being arboreal in habit (Akkemik and Yaman, 2012). Akkemik et al. (2016) also identified Juniperus wood from the Hoçaş Fossil Forest site and given the close anatomical similarity and geographical proximity, we conclude the material described here was probably derived for the same taxon as that found in the Hoçaş Fossil Forest site. Therefore, we assign the material described here to Juniperus species. Recently, Denk et al. (2017b) reported twigs of Juniperus from early Burdigalian deposits of Beskonak (Güvem), which supports evidence for juniper growing in this region during the early Miocene.

\section{Genus SEQUOIA (D. Don) Endlicher, 1847 Sequoia sp.}

Material. INO04, BUG20 and SOG04.

Locality. Within the Beypazarı Inozu Valley on the south side (INO), and near the villages of Çamlıdere-Buğralar (BUG) and Kızılcahamam-Soğuksu (SOG).

Description. The following description was based on ex-situ material collected from three sites with dimensions ranging from 4 to $6.5 \mathrm{~cm}$ in diameter by 6 to $10.5 \mathrm{~cm}$ in height.

Transverse section (TS). Growth ring widths $0.5-3$ $\mathrm{mm}$ with distinct boundaries. Transition from earlywood to latewood abrupt with a wide zone (3-22 cells) of latewood tracheids with reduced radial diameters. No resin canals observed. Tracheid tangential and radial diameters measure 26 (11-42) $\mu \mathrm{m}$ and 29 (14-44) $\mu \mathrm{m}$, respectively, in the earlywood and 17 (5-38) $\mu \mathrm{m}$ and 10 (1-27) $\mu \mathrm{m}$ respec- tively in the latewood. Tracheid wall thickness measures $3(1-9) \mu \mathrm{m}$ (thin walled) in earlywood and $9(1-18) \mu \mathrm{m}$ (thick walled) in latewood. Axial parenchyma common and diffuse to tangentially zonate in the transition zone and latewood. Vascular traces absent (Figure 6).

Tangential longitudinal section (TLS). Rays uniseriate and (low) medium to high (2-27 cells), rarely partly-biseriate. Ray height is $174(28-437) \mu \mathrm{m}$; ray width is $13(6-27) \mu \mathrm{m}$. Helical thickenings absent. Axial parenchyma present with either slightly nodular or smooth transverse end walls; brown contents (possible preservational feature) present in each parenchyma cell (Figure 6).

Radial longitudinal section (RLS). Tracheid pitting generally uniseriate in the latewood, and uni- to biseriate and opposite in the earlywood. Crassulae commonly associated with both uniseriate and biseriate pitting. Two to six taxodioid pits per crossfield and horizontally arranged in one or two rows. No ray tracheids observed. Ray parenchyma walls smooth. Axial parenchyma cells with (brown) contents (Figure 6).

Comments. The combination of wood characters described here is consistent with that of the extant Sequoia/Sequoiadendron/Metasequoia complex and very similar to those fossil woods also identified as Sequoia from the Pelitçik Fossil Forest site located between Beypazarı Inozu Valley (INO) and Kızılcahamam-Soğuksu (SOG) (Akkemik et al., 2009). Further evidence for the presence of Sequoia/Sequoiadendron/Metasequoia comes from leaf imprints and pollen identified from the Güvem area (Kasaplıgil, 1977; Denk et al., 2017b). Sequoia and the Sequoia/Sequoiadendron/Metasequoia complex are the most common tree taxa found growing in Anatolia during the Oligocene (Akkemik et al., 2005; Akkemik and Sakınç, 2013) and into the early to mid-Miocene (Kasaplıgil, 1977; Akkemik et al., 2009; Denk et al., 2017b).

\section{Genus TAXODIUM Richard, 1810 Taxodium sp.}

Material. BUG01.

Locality. Near to the village of Çamlıdere-Buğralar

Description. The following description is based on one poorly preserved ex-situ sample measuring 12 $\mathrm{cm}$ in diameter by $14 \mathrm{~cm}$ in length.

Transverse section (TS). Growth ring boundaries indistinct with ring widths ranging from 0.7 to $2 \mathrm{~mm}$. Transition from earlywood to latewood gradual with a narrow zone (1-3, rarely more) of thin walled, latewood tracheids. Tracheid tangential and radial diameters measure 39 (26-53) $\mu \mathrm{m}$ and 50 (33-63) $\mu \mathrm{m}$, respectively, in the earlywood and 31 (19-50) 

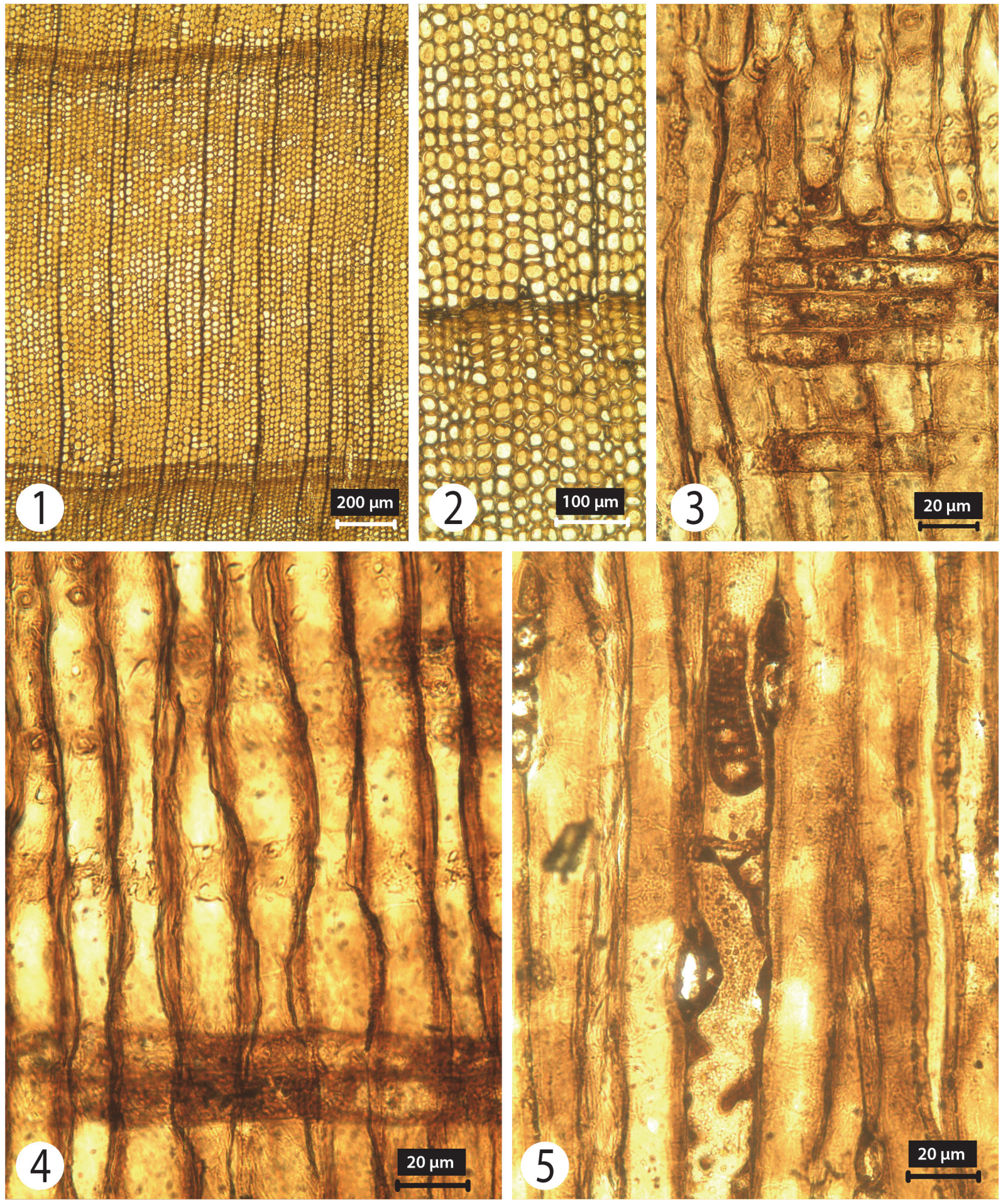

FIGURE 5. Juniperus sp. 1, TS showing growth rings with false rings in summer wood. 2, Close-up of tracheidal arrangement within one growth ring (not inter-tracheidal spaces) and uniseriate rays (TS). 3, RLS showing procumbent cells comprising the ray. 4, RLS showing cupressoid type cross-field pits (RLS). 5, TLS showing axial parenchyma cells with nodular end walls. 

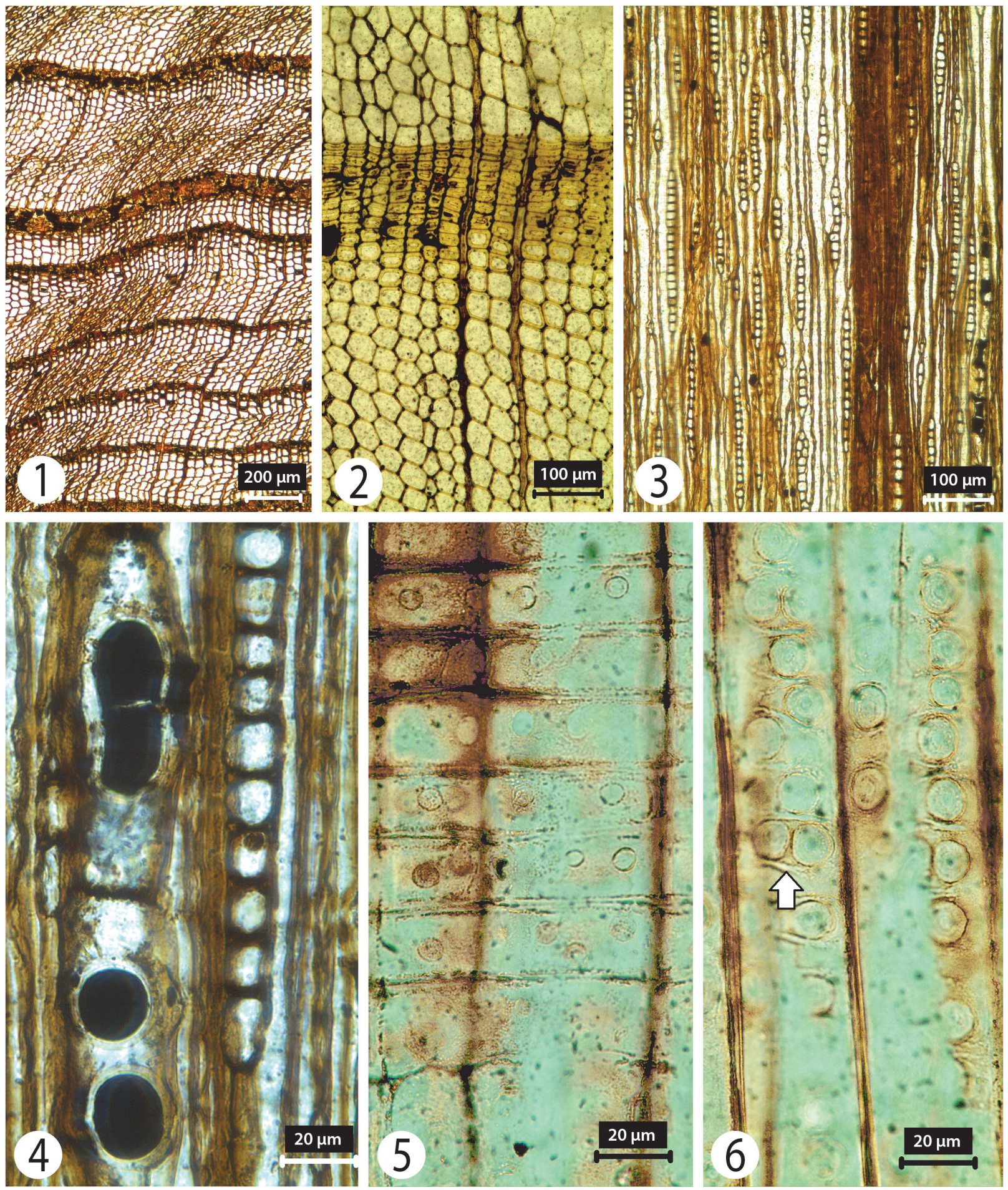

FIGURE 6. Sequoia sp. 1, TS showing distorted (preservational feature) growth rings with clear latewood. 2, TS of one growth ring showing a late wood zone of up to 11 rows of tracheids. 3, TLS showing uniseriate, homogenous rays. 4, TLS showing axial parenchyma cells with smooth end walls and dark contents (preservational feature). 5, Rays with taxodioid type cross-field pits (RLS). 6, Bordered pits in one and two rows with crassulae visible (arrow) (TLS). 

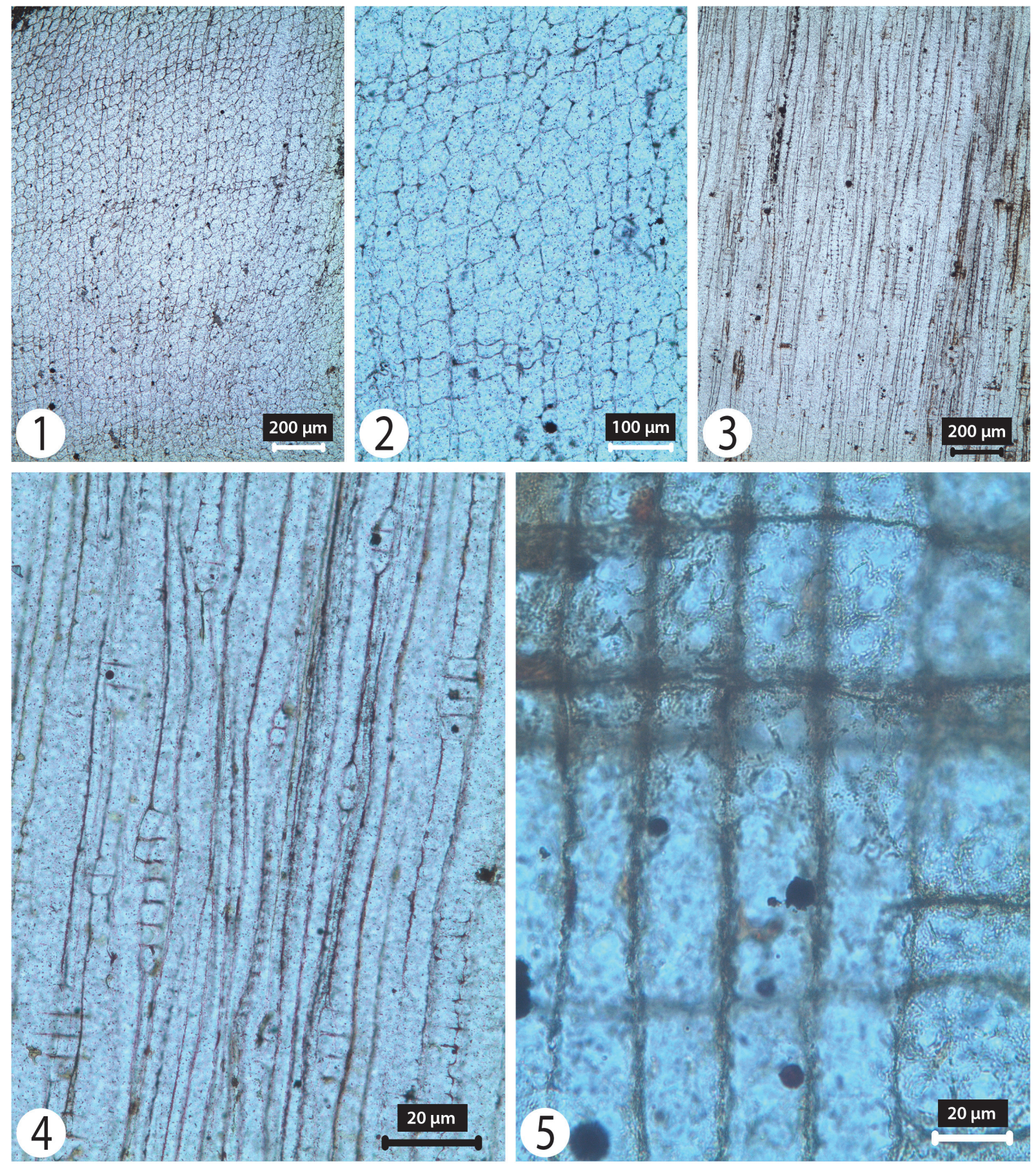

FIGURE 7. Taxodium. 1, TS showing very narrow, indistinct growing rings. 2, TS showing latewood zones of only 2 rows of tracheids. 3-4, TLS showing uniseriate rays. 5, Rays with taxodioid type cross-field pits (RLS).

$\mu \mathrm{m}$ and $27(20-37) \mu \mathrm{m}$, respectively, in the latewood. Tracheid wall thickness measures $3(1-5)$ $\mu \mathrm{m}$ (thin walled) in earlywood and $3(1-4) \mu \mathrm{m}$ (thin walled) in latewood. Axial parenchyma diffuses and rare. Resin canals absent (Figure 7).
Tangential longitudinal section (TLS). Rays uniseriate, rarely partly biseriate and homogenous. Rays measure 422 (303-569) $\mu \mathrm{m}$ in height and 18 (627) $\mu \mathrm{m}$ in width. Tracheidal pitting rare, uniseriate and non-contiguous. Helical thickening absent (Figure 7). 
Radial longitudinal section (RLS). Tracheid pitting uniseriate or biseriate (rarely triseriate) and opposite. Rays low. Three to seven seemingly taxodioid pits per cross field both horizontally and randomly arranged. Ray tracheids absent. Ray parenchyma walls smooth (Figure 7).

Comments. The combination of wood characters described here is consistent with that of Taxodium. Akkemik et al. (2009) identified this genus from Pelitçik, a site proximal to Çamlıdere-Buğralar Village (Figure 1). Taxodium is one of the more frequently encountered tree genera from the early Miocene with micro- and macrofossils having been identified from Anatolia (Kasaplıgil, 1977; Akkemik et al., 2009), Italy (Biondi and Brugiapaglia, 1991) and Greece (Velitzelos et al., 2014).

Family PINACEAE Sprengel ex F. Rudolphi, 1830 Genus CEDRUS Trew, 1757

\section{Cedrus sp.}

Material. INL03, INO05 and INO06.

Localities. Within the Beypazarı-Inozu Valley on the south side (INO) and north side (INL).

Description. All samples are ex-situ with dimensions ranging from 7 to $10 \mathrm{~cm}$ in length and 2 to 4.5 $\mathrm{cm}$ in diameter.

Transverse section (TS). Growth ring width ranging from 0.4 to $1.5 \mathrm{~mm}$. Growth ring boundaries distinct with transition from earlywood to latewood gradual. Latewood zone is generally wide (5-30 cells in radial direction). Tangential and radial tracheid diameters measure $21(6-38) \mu \mathrm{m}$ and $30(15-52)$ $\mu \mathrm{m}$, respectively, in the earlywood and 13 (4-26) $\mu \mathrm{m}$ and $7(1-15) \mu \mathrm{m}$, respectively, in latewood. Tracheid wall thickness measures 5 (1-9) $\mu \mathrm{m}$ (thin walled) in earlywood and 12 (5-21) $\mu \mathrm{m}$ (thick walled) in latewood. Axial parenchyma marginal, diffuse or in 2-3 rows. Resin canals absent although traumatic resin canals in both the latewood and transition zones of some rings are common (Figure 8).

Tangential longitudinal section (TLS). Rays entirely uniseriate, 13-22 cells high or 215 (27-1004) $\mu \mathrm{m}$ in height and 12 (4-31) $\mu \mathrm{m}$ in width. Many traumatic vertical resin canals observed, rays with horizontal resin canals absent (Figure 8).

Radial longitudinal section (RLS). Rays are heterogeneous. Smooth walled ray tracheids are common and form 1-2 rows with enlarged cells when situated towards the outside of the rays. End- and horizontal walls of ray parenchyma cells are distinctly pitted. Tracheid pitting in radial walls (in early wood) is predominantly uniseriate with scalloped tori. Cross-field pitting is cupressoid with 1-4 pits per cross-field (Figure 8).
Comments. Woods with resin canals also occur in wood of Pinus and Picea but differ in that they are arranged in one row within each growth ring. The combination of wood characters described here is consistent with that of Cedrus. Cedrus fossils have been described from the central part of the GVP. Denk et al. (2017b) reported a seed of Cedrus at Güvem and pollen, which is considered to be relatively common in the Güvem area, by Yavuz-Isik (2008). At the Hoçaş Fossil Forest site in the west Akkemik et al. (2016) identified the wood of Cedrus. The published wood characteristics of extant Cedrus libani A. Rich. (Akkemik and Yaman, 2012) are virtually identical to those of the petrified woods but although identical at species level, when the age of the material is considered we cannot ignore the fact that this material might be a representative of an ancestral lineage (Akkemik et al., 2016) and for this reason these specimens are referred to Cedrus. as Cedrus cf. libani. Today one species, Cedrus libani (Taurus cedar), grows in the Mediterranean Region of Turkey. However, two more species (C. brevifolia A. Henry ex Elwes et A. Henry and $C$. atlantica [Endl.] Manetti ex Carrière) are native to land surrounding the Mediterranean Sea.

\section{Genus PICEA A. Dietrich, 1824 Picea sp.}

Material. AGUD2 and KUZ20.

Localities. Near the villages of BeypazarıAşağıgüney and Bolu-Kıbrısçık-Kuzca- Alanhümmet.

Description. The following description is based on two specimens, one in situ AGUD2 in life position whereas the second, KUZ20, is in situ. Dimensions of the samples range from $11-17 \mathrm{~cm}$ in height/ length and $5.5-7.5 \mathrm{~cm}$ in diameter.

Transverse section (TS). Growth ring boundaries distinct with transition from earlywood to latewood gradual. Growth ring width is very wide, $3.5-9 \mathrm{~mm}$. Tracheid tangential and radial diameters measure $17(8-26) \mu \mathrm{m}$ and $24(9-54) \mu \mathrm{m}$, respectively, in earlywood, and 8 (4-16) $\mu \mathrm{m}$ and 7 (1-18) $\mu \mathrm{m}$, respectively, in latewood. Tracheid wall thickness measures $3(1-6) \mu \mathrm{m}$ (thin walled) in earlywood and 5 (2-9) $\mu \mathrm{m}$ (thick walled) in latewood. Resin canals common and surrounded by epithelial cells of varying dimensions (Figure 9), sometimes paired and generally restricted to transition zone; tangential and radial diameters measure 129 (75192) $\mu \mathrm{m}$ and 141 (112-193) $\mu \mathrm{m}$, respectively.

Tangential longitudinal section (TLS). Rays generally uniseriate unless with horizontal resin canals. Rays with resin canal uniseriate to partly biseriate. Rays measure 298 (128-405) $\mu \mathrm{m}$ in height when 

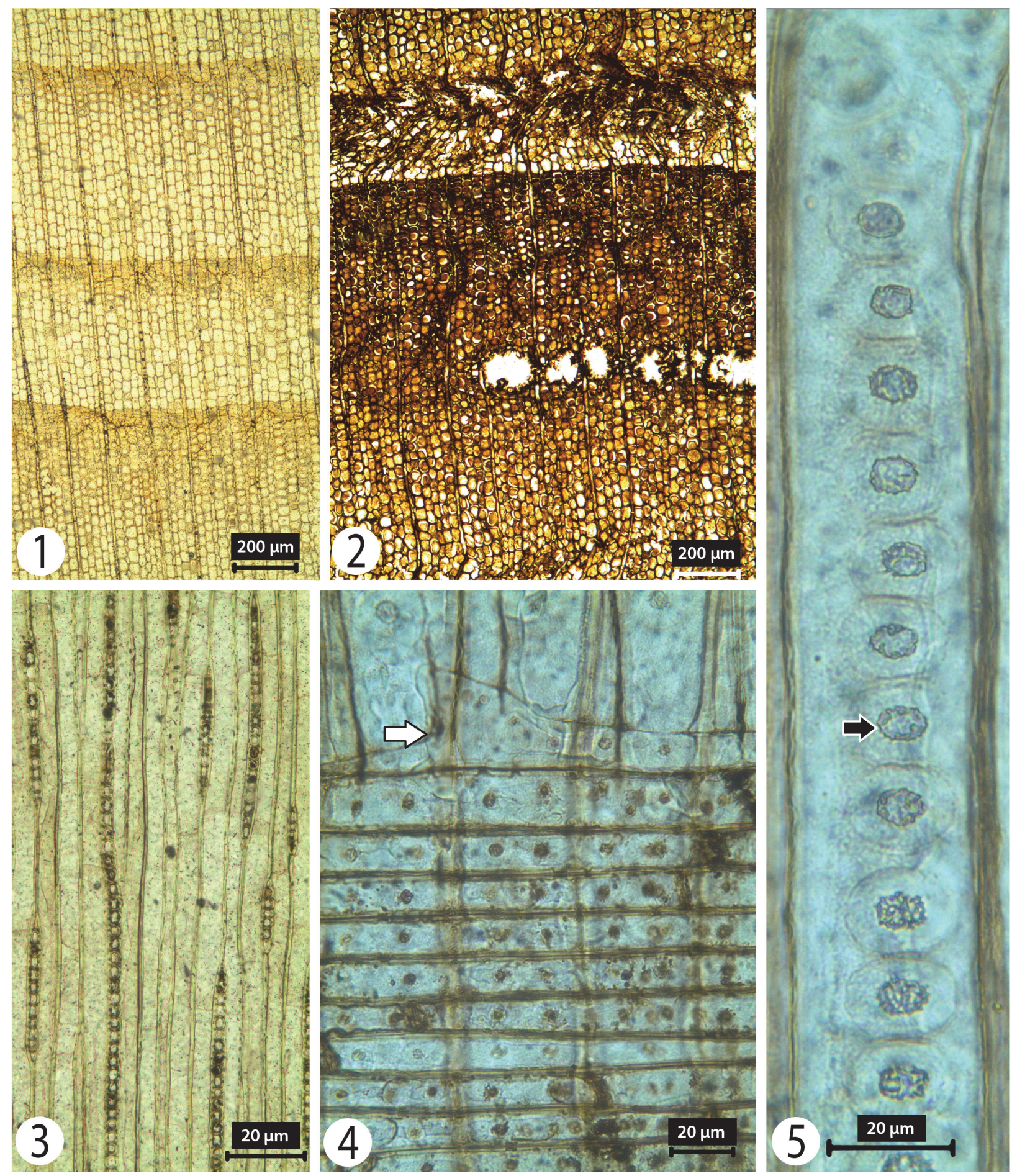

FIGURE 8. Cedrus. 1, TS showing clear growth rings and no (traumatic) resin canals. 2, TS showing growth rings and associated traumatic resin canals. 3, TLS showing uniseriate rays. 4, RLS showing rays with ray tracheids (white arrow) and cupressoid type cross-field pits. 5, Bordered pits with scalloped tori (RLS) (black arrow). 

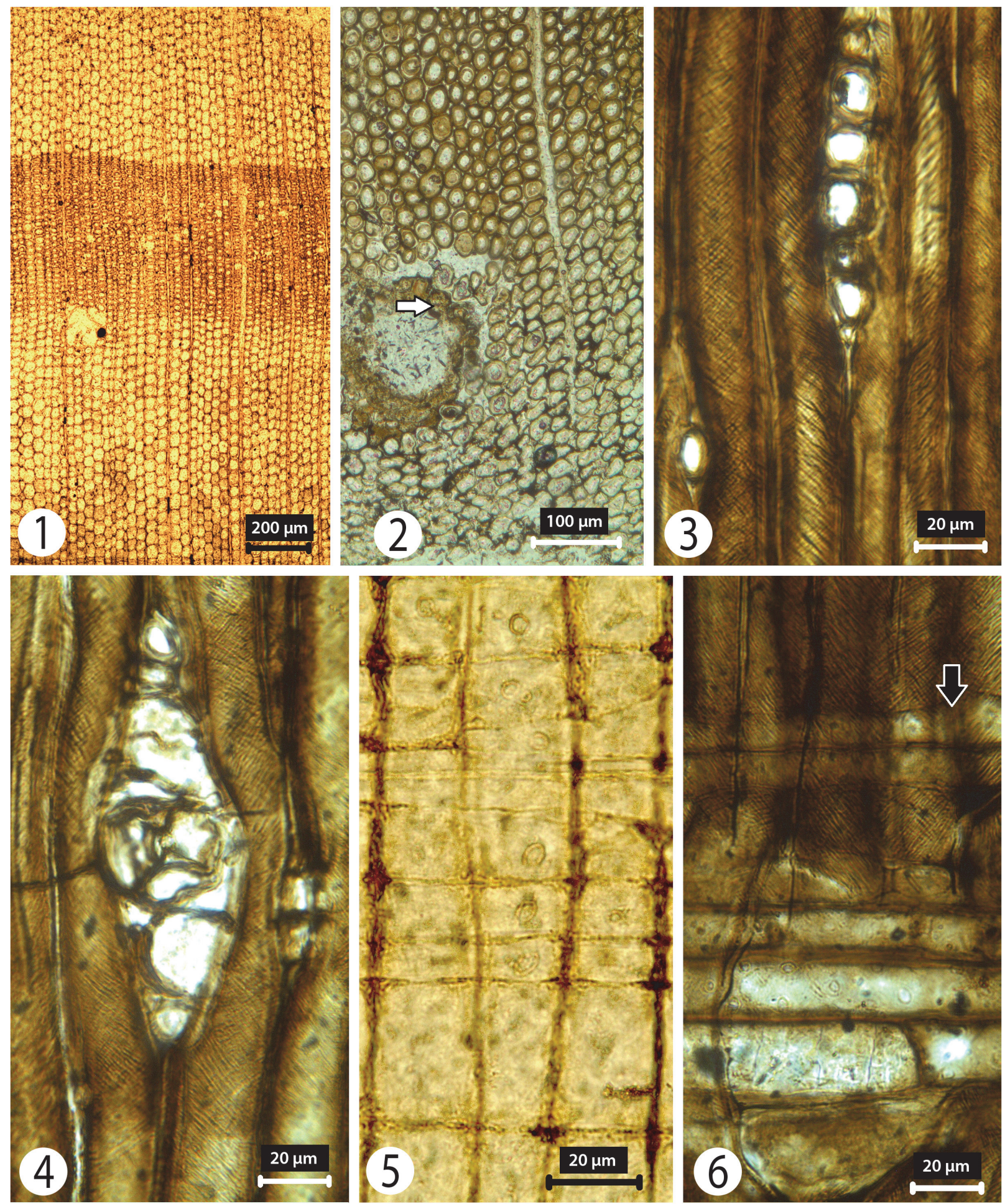

FIGURE 9. Picea. 1, TS showing wide growth rings and resin canal. 2, TS resin canal with no visible epithelial cells (white arrow). 3, TLS showing a ray without any horizontal resin canals and tracheids with helical thickenings. 4, TLS showing a ray with a horizontal resin canal and helical thickenings in the tracheids. 5, Cupressoid type cross-field pits. 6, Ray tracheid (black arrow) with smooth wall and cupressoid type pits in the cross-fields (RLS). 
resin canals are present, and $144(28-353) \mu \mathrm{m}$ in those rays without resin canal; ray widths measure $44(38-48) \mu \mathrm{m}$ in those rays with resin canals, and $12(6-20) \mu \mathrm{m}$ in rays without resin canals. When present in rays, resin canals are surrounded by a layer of epithelial cells. Helical thickenings are very common in AGUD2 but absent in KUZ20 (Figure 9).

Radial longitudinal section (RLS). Rays heterogeneous. Ray tracheids common in 1-2 rows with smooth, thin walls, rarely slightly wavy. Both horizontal and end walls of ray parenchyma cells are distinctly pitted. Cross-field pitting is cupressoid with 1-3 pits per cross-field. Tracheid pitting in radial walls of the early wood is predominantly uniseriate (Figure 9).

Comments. The combination of wood characters described here is consistent with that of Picea. Today Picea is represented by three species around the Mediterranean and Europe (i.e., Picea abies (L.) Karsten, P. omorika (Panèiæ) Purkyne, and $P$. orientalis (L.) Link.), but identification to species level is not always possible using wood characters alone. Within these three species, Schweingruber (1990) notes that cross-field pitting is generally cupressoid in Picea abies (and Picea omorika, whereas Akkemik and Yaman (2012) have observed piceoid cross-field pitting in Picea orientalis. Our samples exhibit predominantly cupressoid cross-field pitting suggesting that the material is probably more similar to European Picea species, but the fossil wood differs from all extant European and Mediterranean species by the presence of helical thickening. Therefore, the fossil material described here is assigned to Picea sp.

\section{Genus PINUS Linnaeus, 1753 Pinus sp.}

Material. AGU01, AGU22, AGU23, INO12, KIR21, KUZ01, KUZ07, KUZ09, KUZ17, MEN32 and MEN33 (in situ); AGUD12 and KUZ01 (in situ).

Localities. Near the villages of BeypazarıAşağıgüney (AGU), Beypazarı-Nuhhoca (Kıraluç Site) (KIR), Bolu-Kıbrısçık-Kuzca- Alanhümmet (KUZ) and Beypazarı-Mençeler (MEN), and in the Beypazarı Inozu Valley (south side) (INO).

Description. In situ and in situ material with dimensions ranging from 9 to $16 \mathrm{~cm}$ in height/ length by 2 to $8.5 \mathrm{~cm}$ in diameter.

Transverse section (TS). Growth ring boundaries distinct with transition from earlywood to latewood abrupt in AGU22 and KIR21, and gradual in the others. Width of growth rings range from 1-3.5 to 7 $\mathrm{mm}$ with a mode of $4-5 \mathrm{~mm}$; i.e., generally wide except in specimen AGU22. Tracheid tangential and radial diameters measure $25(6-59) \mu \mathrm{m}$ and $29(9-55) \mu \mathrm{m}$, respectively, in the earlywood and $10(1-38) \mu \mathrm{m}$ and $7(1-22) \mu \mathrm{m}$, respectively, in the latewood; tracheid wall thickness measure 4 (115) $\mu \mathrm{m}$ (thin walled) in earlywood and $6(1-19) \mu \mathrm{m}$ (thick walled), respectively, in latewood. Resin canals present, frequent in the earlywood-latewood transition zone; thin-walled epithelial cells observed surrounding some resin canals (Figure 10). Tangential and radial diameters of resin canals are $138(41-354) \mu \mathrm{m}$ and $139(61-295) \mu \mathrm{m}$, respectively.

Tangential longitudinal section (TLS). Rays with and without horizontal resin canals. Rays without horizontal canals are uniseriate, 144 (29-425) $\mu \mathrm{m}$ in height and $14(4-30) \mu \mathrm{m}$ in width. Rays with resin canals present measure $301(83-501) \mu \mathrm{m}$ in height and 41 (13-67) $\mu \mathrm{m}$ in width (Figure 10).

Radial longitudinal section (RLS). Rays heterogeneous. Ray tracheids commonly in 1-4 rows with smooth walls, rarely slightly wavy. Both transverse walls and end walls of ray parenchyma cells are unpitted. Cross-field pitting is clearly pinoid with 12 pits per cross-field. Tracheid pitting uniseriate (Figure 10).

Comments. The combination of wood characters such as resin canals, heterogeneous rays and pinoid type cross-field pitting place this morphotaxon within the genus Pinus. Today Turkey is represented by five species of Pinus, namely $P$. nigra Arnold, P. sylvestris L., P. brutia Ten., P. pinea L. and $P$. halepensis Miller. The fossils show greatest anatomical similarity to Pinus pinea with its smooth ray tracheids and 1-2 pinoid type of pits per crossfield (Akkemik and Yaman, 2012). Pinus wood has also been identified from the Kozyaka Fossil Forest site (Figure 1) in the west part of GVP (Akkemik et al., 2016), and other macrofossil (leaf and cone) evidence (Kasaplıgil, 1977; Denk et al., 2017b) found at both the Güvem and Hoçaş sites (Figure 1) that revealed Pinus comprised both the three needled and five needled varieties. With this in mind, it cannot be assumed that all Pinus fossil evidence originated from the same taxon. Moreover, since identification to species based on wood anatomy alone is often inconclusive, we refer the specimens described herein to Pinus.

Family PODOCARPACEAE Endlicher, 1847

Genus PODOCARPUS L'Heritier ex Persoon, 1807

Podocarpus sp.

Material. KIR40, KIR70, KIR73 and MEN19. 

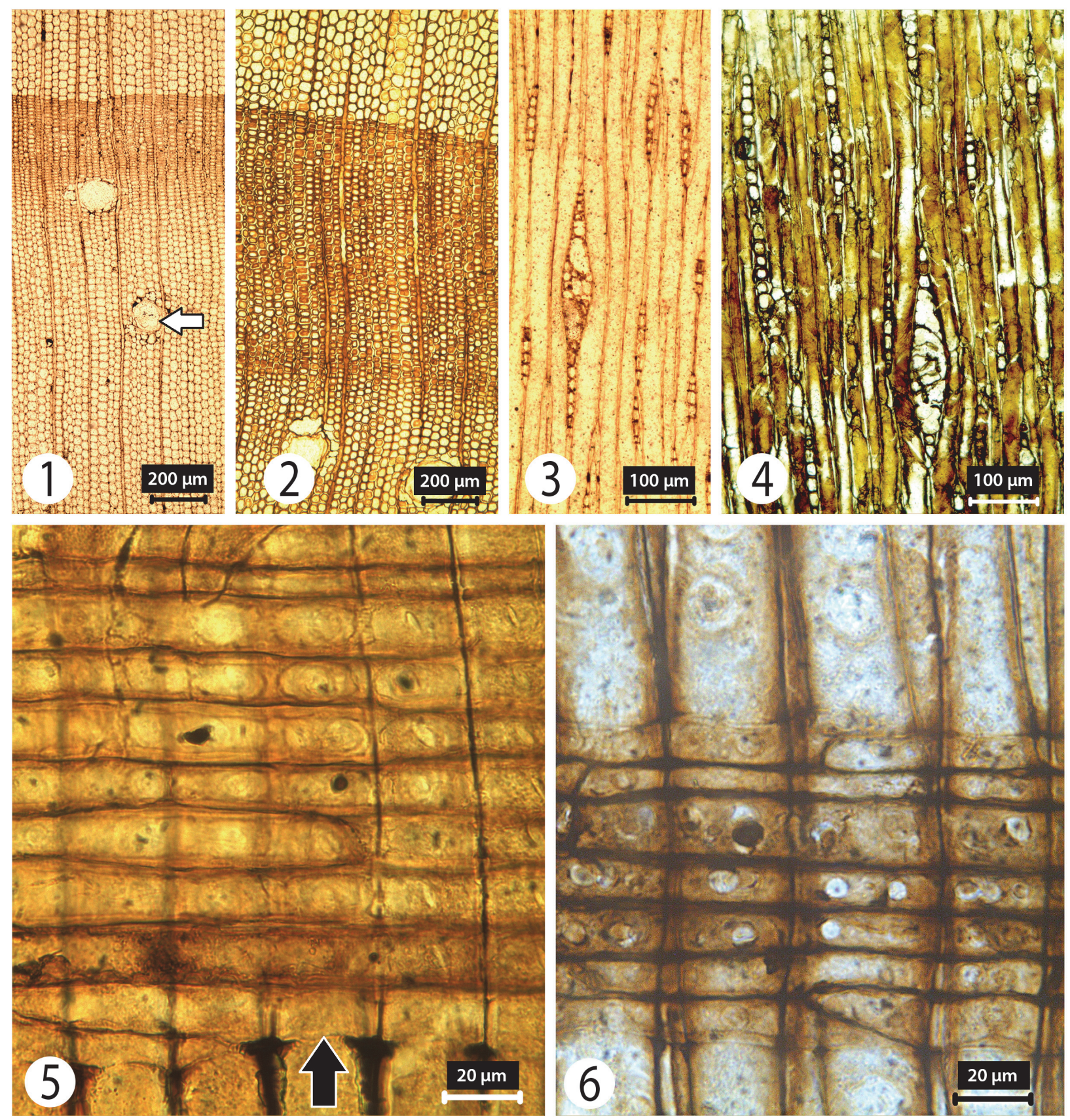

FIGURE 10. Pinus. 1, TS showing wide growth rings and resin canal. 2, TS resin canal with no visible epithelial cells (white arrow). 3-4, Rays with and without horizontal resin canal and tracheids (TLS). 5, RLS showing procumbent cells forming the ray. $\mathbf{6}$, Pinoid type cross-field pits, and ray tracheids (black arrow) with smooth walls.

Localities. Near the village of Beypazarı-Nuhhoca (Kıraluç Site) (KIR) and in the Beypazarı-Mençeler Valley (MEN).

Description. All samples are ex-situ and dimensions range from $6-7 \mathrm{~cm}$ in height and $1-4 \mathrm{~cm}$ in diameter. One sample, KIR40, is very poorly preserved, and some features were not observed.
Transverse section (TS). Growth rings boundaries distinct with ring widths ranging from 0.4 to 1.2 $\mathrm{mm}$; transition from earlywood to latewood almost abrupt, with 4-7 rows of latewood tracheids in KIR73 but gradual in KIR70. Resin canals absent (Figure 11). Tracheid tangential and radial diameters measure $22(5-40) \mu \mathrm{m}$ and $23(10-45) \mu \mathrm{m}$, respectively, in the earlywood, and 14 (7-22) $\mu \mathrm{m}$ 

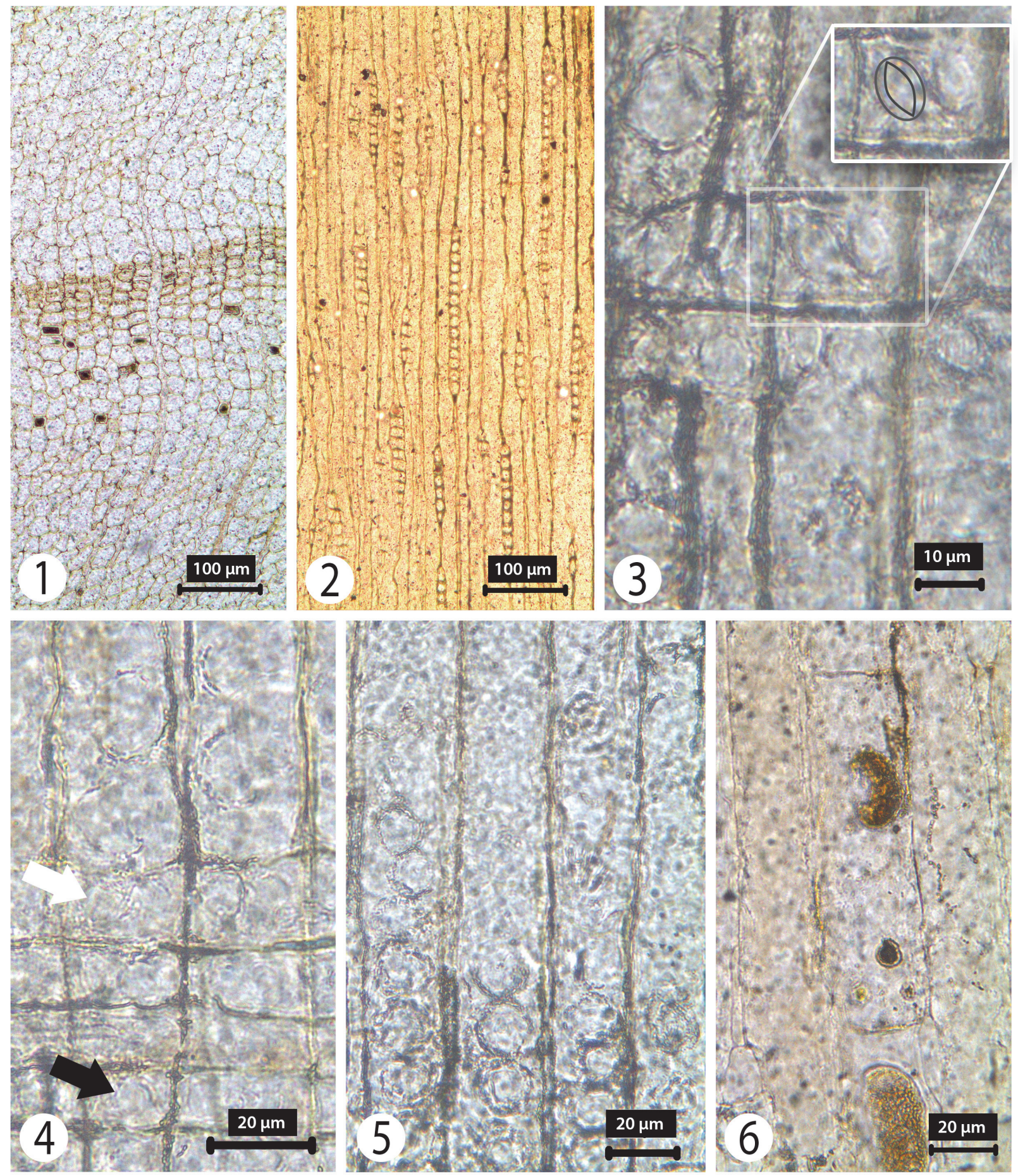

FIGURE 11. Podocarpus. 1, TS across one growth ring with diffuse axial parenchyma cells. 2, Homogenous uniseriate rays (TLS). 3, RLS showing large cupressoid and taxodioid type cross-field pits with two cross-field pits shown in the upper box. Left indicates the borders of pit drawn, right shows the oblique appearance of the pit. 4, RLS showing procumbent nature of the cells forming the ray, and cross-field pits; white arrow indicates the oblique position of the pit; black arrow shows vertical pit. 5, Radial pitting with one row in large (earlywood) tracheids. 6, Axial parenchyma cells with thin end walls (vertical arrow). 
and $7(1-15) \mu \mathrm{m}$, respectively, in the latewood. Tracheid wall thickness is $3(1-5) \mu \mathrm{m}$ (thin walled) in the earlywood and $5(1-12) \mu \mathrm{m}$ (thick walled) in the latewood. Axial parenchyma common, diffuse and in short tangential bands both through the transition zone and in late latewood (Figure 11).

Tangential longitudinal section (TLS). Rays uniseriate, homogenous, very rarely biseriate, mostly short, 5-15 (2-21) cells in height or 95 (22-347) $\mu \mathrm{m}$ high and 10 (4-18) $\mu \mathrm{m}$ in width (Figure 11).

Radial longitudinal section (RLS). Tracheid pitting on radial walls, uniseriate with abietinean radial pitting (i.e., spaced and uniseriate; sensu Philippe and Bamford, 2008)—round, not contiguous, relatively large with diameters of $16-19 \mu \mathrm{m}$. Poor preservation has mostly rendered only the outer borders of tracheid pits recognizable. Generally, two (1-3) pits per cross-field, large cupressoid and taxodioid. Vertical and oblique apertures observed in some pits (Figure 11). Horizontal cross-field pits were not observed.

Comments. The combination of wood characters including the presence of distinct growth rings, uniseriate bordered pits on radial walls and 1-2 (up to 3) large cupressoid and taxodioid pits per cross field place this material within the genus Podocarpus (Brezinova et al., 1994). Since identification to species based on wood anatomy alone is often inconclusive, we refer these specimens to Podocarpus. Fossil woods of putative affinity to the Podocarpaceae have been described by many authors and assigned to Podocarpoxylon Gothan, Protopodocarpoxylon Eckhold, Phyllocladoxylon Gothan, Mesembrioxylon Seward, Metapodocarpoxylon Duperon-Laudoueneix and Pons, Protophyllocladoxylon Kräusel, Circoporoxylon Kräusel and even Cupressinoxylon Göeppert (Pujana and Ruiz, 2017). Pujana and Ruiz (2017) have recently reviewed fossil Podocarpoxylon woods and conclude that although many supposed woods of the podocarpaceous type have been found in the Northern Hemisphere, the deficit of other podocarpaceous fossil remains substantiates the fact that this the fossil genus may include wood from taxa other than those of Podocarpaceae. Possible podocarpaceous woods have previously been identified: Süss and Velitzelos (2000) identified two Podocarpoxylon wood species from the lower Miocene of Lesbos, and from Thrace (Sakınç et al., 2007) and Akkemik (work in progress) have both identified wood samples as Podocarpoxylon. This suggests a possible podocarpaceous tree grew across this area during the early Miocene. The sample described here is the first record of Podocarpus in the wood flora of GVP.

$$
\begin{gathered}
\text { Family FAGACEAE Dumortier, } 1829 \\
\text { Genus QUERCUS Linnaeus, } 1753 \\
\text { Quercus section Ilex sp. }
\end{gathered}
$$

Material. INL09, KIR07, KAR01, MEN02, MEN22 and MEN28.

Localities. Within the Beypazarı-Inozu valley (north side) (INL) and the Beypazarı-Mençeler valley (MEN) and near to the villages of BeypazarıNuhhoca (Kıraluç Site) (KIR) and BeypazarıKaraşar (KAR).

Description. All samples are in situ and range from 4 to $12 \mathrm{~cm}$ in length and 4 to $8.5 \mathrm{~cm}$ in diameter.

Transverse section (TS). Growth ring boundaries indistinct, wood diffuse porous. Vessel tangential diameter 82 (22-182) $\mu \mathrm{m}$, and radial diameter 109 (33-206) $\mu \mathrm{m}$; average vessel density is 22 (13-29) vessels per $\mathrm{mm}^{2}$. Tyloses common in wider vessels. Large multiseriate rays can clearly be seen with the naked eye. In well-preserved woods axial parenchyma is clearly visible arranged in short tangential bands in single rows (Figure 12).

Tangential longitudinal section (TLS). Rays number 4-6 per $\mathrm{mm}$ and are of two distinct sizes. Narrow uniseriate and biseriate rays measure 334 (110$805) \mu \mathrm{m}$ by 14 (4-26) $\mu \mathrm{m}$ in width; large multiseriate rays range from 10 to 20 cells, or 258 (67-411) $\mu \mathrm{m}$, in width by $>1 \mathrm{~mm}$ in height (Figure 12).

Radial longitudinal section (RLS). Perforation plates are simple. Rays are homocellular and composed of procumbent ray cells (Figure 12).

Comments. The combination of characters outlined above indicate that this wood type belongs to Quercus L. and in particular the Quercus section Ilex wood type given that all these fossil specimens are diffuse porous (as opposed to ring porous, characteristic of Quercus Sections Quercus and Cerris). Furthermore, macrofossils of Quercus section Ilex (Denk et al., 2017a, 2017c) and pollen (Yavuz-Işık, 2008) have also been found from the Güvem region.

This wood type, which may represent a lineage ancestral to the modern western Eurasia sclerophyllous oaks, has also been found at the Hoçaş site (Figure 1) (Akkemik et al., 2016). Akkemik et al. (2016) concluded that the presence of evergreen oak species found at a total of five fossil sites in GVP suggested that this taxon was not an uncommon element of the early Miocene vegetation. Further studies on modern oaks and sediments around the Mediterranean Basin (Denk and Grimm, 2009, 2010; Hubert et al., 2014; Denk et 

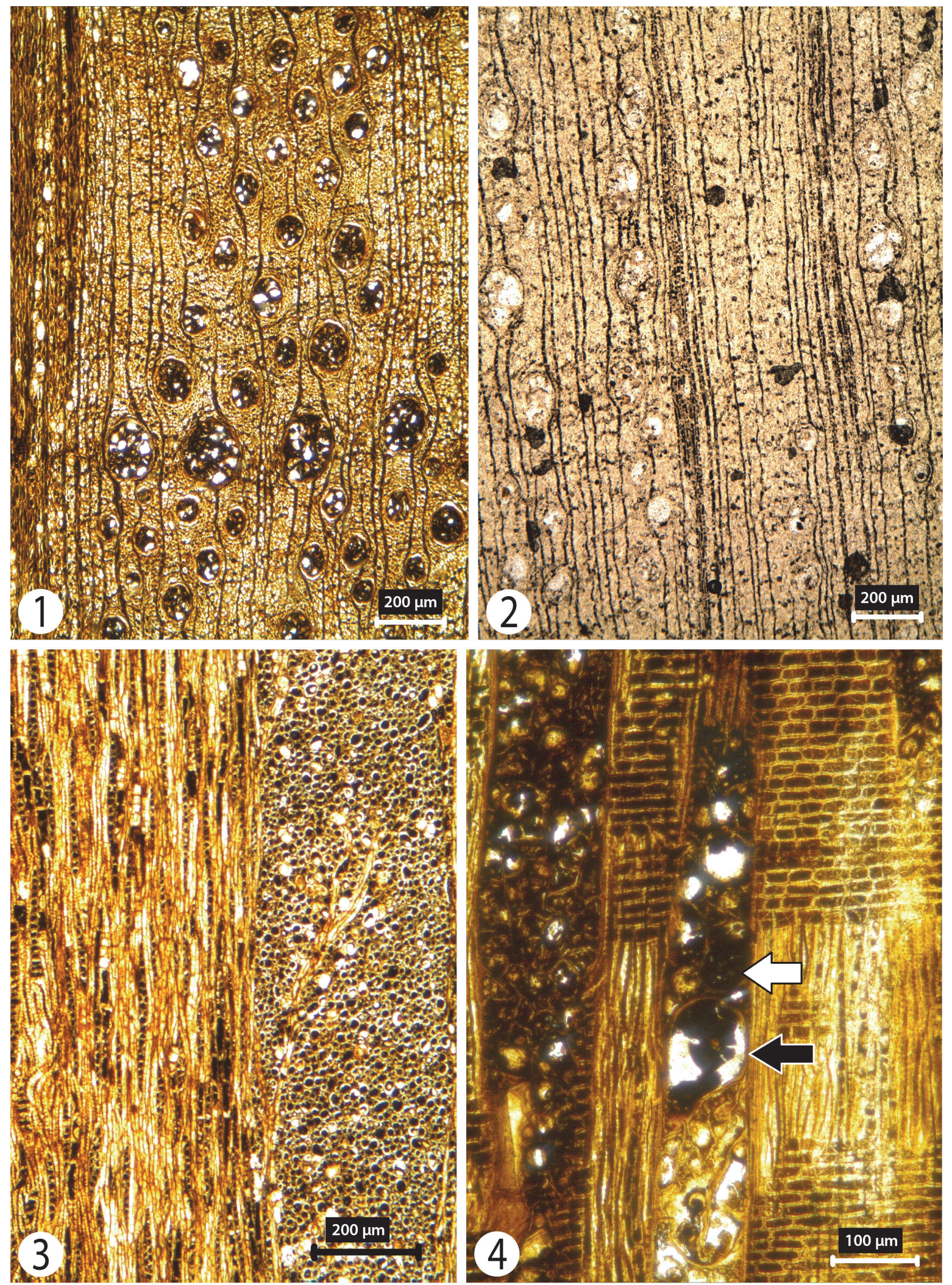

FIGURE 12. Quercus (section Ilex). 1, TS showing solitary vessels with tyloses and one multiseriate ray. 2, TS showing radial alignment of the solitary vessels and uniseriate rays. 3, TLS showing rays of two sizes. 4, RLS of rays with procumbent cells, vessel with a simple perforation plate (black arrow) and filled with tyloses (white arrow). 
al., 2017c) suggest a Eurasian group of evergreen oaks, comprising about 30 species, that occurred across the Mediterranean region and extended into the southern foothills of the Himalayas and across East and Southeast Asia during the early Miocene. The material found on the GVP may belong to this Eurasian group.

Family OLEACEAE Hoffmannsegg and Link, 1809 Genus FRAXINUS Linnaeus, 1753 Fraxinus sp.

Material. AGU13.

Locality. Near the village of BeypazarıAşağıgüney (AGU).

Description. The following description is based on one piece of in situ material measuring $16 \mathrm{~cm}$ in length and $8 \mathrm{~cm}$ in diameter.

Transversal section (TS). Growth ring boundaries distinct, with ring widths ranging from 2.3 to $5 \mathrm{~mm}$. Wood ring-porous. Earlywood vessels wide becoming narrower in the latewood. Tangential and radial diameters of vessel lumen $69(26-116) \mu \mathrm{m}$ and $90(33-130) \mu \mathrm{m}$, respectively, in the earlywood, and in the latewood tangential and radial diameters measure 27 (13-46) $50 \mu \mathrm{m}$ and 24 (1152) $\mu \mathrm{m}$, respectively. Vessel density 83 (67-104) vessels per $\mathrm{mm}^{2}$ with $26(23-32)$ vessels per $\mathrm{mm}^{2}$ in earlywood and 57 (44-72) vessels in latewood. Vessels solitary and in radial multiples of up to three vessels. Paratracheal axial parenchyma almost lozenge-aliform especially in the latewood (Figure 13).

Tangential longitudinal section (TLS). Rays uniseriate to biseriate sometimes triseriate. Rays number $\geq 12$ per mm (Figure 13) and measure 216 (58345) $\mu \mathrm{m}$ in height and $23(11-38) \mu \mathrm{m}$ in width. Perforation plates simple. Fibres thin- to thick-walled (Figure 13).

Radial longitudinal section (RLS). Homocellular in some rays with all ray cells entirely procumbent others are heterocellular with procumbent body ray cells and square/upright marginals (Figure 13).

Comments. The combination of wood characters including ring porous vessels, distinct growth ring borders, clear transition from earlywood to latewood, sparse vessels in the latewood, rays 1-3 seriate with mostly procumbent body cells and slightly lozenge-aliform axial parenchyma shows closest anatomical similarity to Fraxinus L. (Akkemik and Yaman, 2012) and has thus been assigned to Fraxinus sp. Although Fraxinus is represented by four species, F. excelsior L., F. angustifolia Vahl., F. ornus L. and F. pallisae Wilmott. In Turkey today, this study represents the first record of Fraxinus wood material from the GVP (and from
Turkey as a whole). Other macrofossil and palynological evidence including leaves (Kasaplıgil, 1977), fruits (Denk et al., 2017b) and pollen (Karayiğit et al., 1999) supports the presence of Fraxinus growing in the Güvem Basin at this time.

\section{Family ROSACEAE Jussieu, 1789 \\ Genus PRUNUS Linnaeus, 1753 Prunus sp.}

Material. MEN31.

Locality. Beypazarı-Mençeler Valley (MEN).

Description. The following description is based on one piece of ex-situ material measuring $10 \mathrm{~cm}$ in length and $7 \mathrm{~cm}$ in width.

Transverse section (TS). Wood ring porous, sometimes more semi-ring porous, with distinct growth ring boundaries and ring widths ranging from 0.4 to $1 \mathrm{~mm}$ in width. Tangential and radial diameters of vessels measure $55(32-75) \mu \mathrm{m}$ and $82(33-136)$ $\mu \mathrm{m}$, respectively, in the earlywood, and 22 (8-43) $\mu \mathrm{m}$ and $30(15-50) \mu \mathrm{m}$, respectively, in latewood. Vessels solitary or in short radial files of $2-4$. Vessel density 67 (55-78) per $\mathrm{mm}^{2}$ (Figure 14).

Tangential longitudinal section (TLS). Rays number 4-12 per $\mathrm{mm}$ and are clearly of two distinct sizes (Figure 14); wide rays 4-10 seriate, or 66 (51-78) $\mu \mathrm{m}$ in width, and $>1 \mathrm{~mm}$ in height; narrow rays uniseriate (very rarely biseriate), or 7 (4-11) $\mu \mathrm{m}$ in width, and 117 (67-156) $\mu \mathrm{m}$ in height.

Radial longitudinal section (RLS). Rays heterocellular with procumbent body ray cells and one or more rows of upright and/or square marginal cells. Perforation plates simple. Intervessel pits are alternate or loosely opposite (Figure 14).

Comments. The combination of ring porous wood, relatively wide and long heterocellular rays and simple perforation plates suggest greatest affinity with Prunus. Today there are four species of Prunus growing in Turkey (Akkemik and Eminağaoğlu, 2014). Akkemik and Yaman (2012) described the wood anatomy of Prunus cocomilia Ten. from the Mediterranean region. The characters of this silicified wood exhibit strong anatomical similarity to the extant species but since species of Prunus are difficult to determine from wood anatomy alone this fossil type is assigned to Prunus sp. and represents the first record of fossilized Prunus wood from both the GVP and Turkey.

$$
\begin{gathered}
\text { Family SALICACEAE Mirbel, } 1815 \\
\text { Genus SALIX Linnaeus, } 1753 \\
\text { Salix sp. }
\end{gathered}
$$

Material. KIR59, MEN30 and MEN34 measuring $5-7 \mathrm{~cm}$ in diameter and 9-13 cm high. 

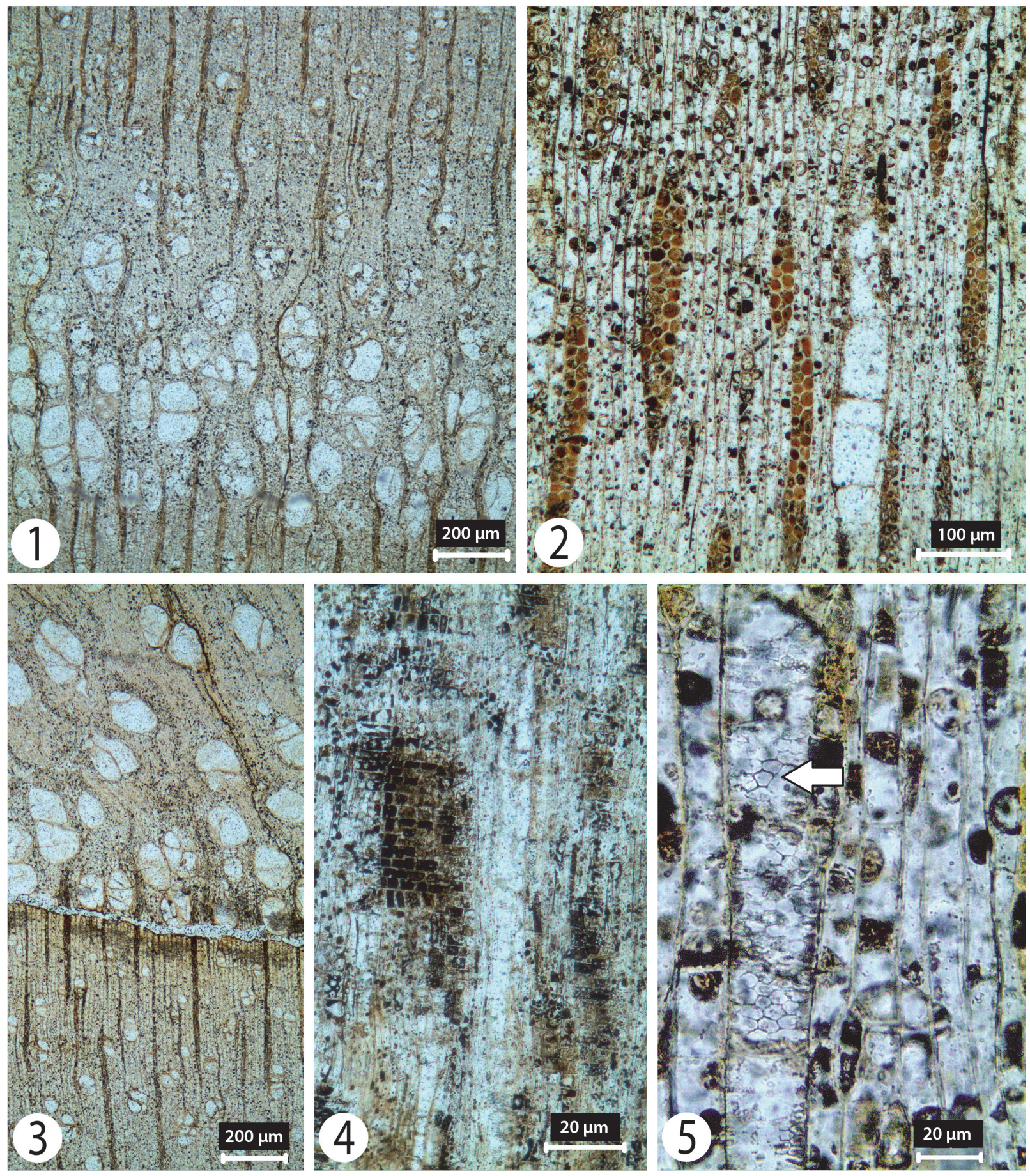

FIGURE 13. Fraxinus. 1, TS showing ring porous nature of the wood. 2, RLS of triseriate rays. 3, TS showing distortion in the early wood caused during preservation. 4, Rays with both procumbent and upright cells (RLS). 5, Axial parenchyma cells and a vessel with alternate bordered pits. 

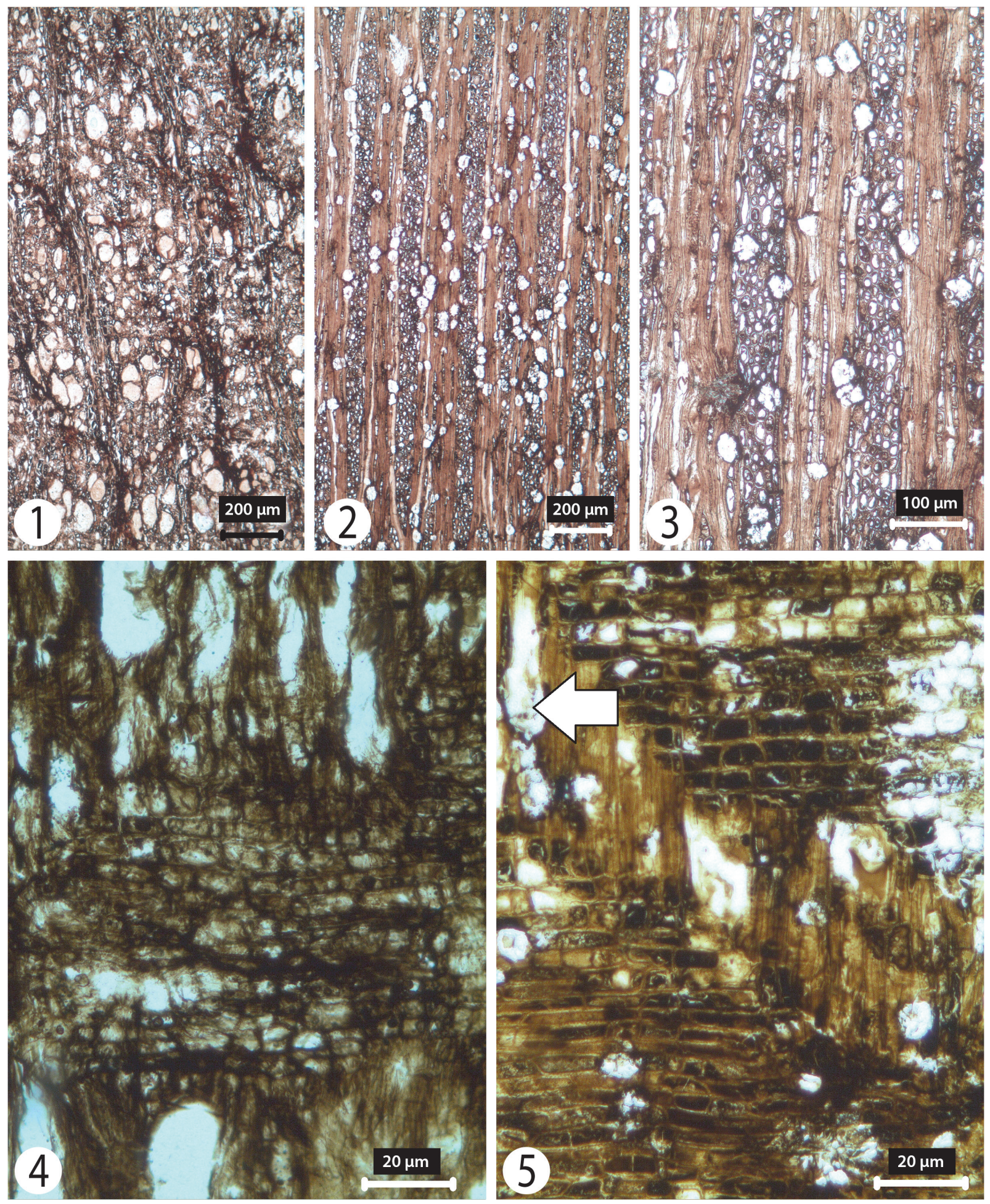

FIGURE 14. Prunus. 1, TS showing relatively unclear preservation caused by distortion during preservation and ringporous vessels. 2 , TLS showing the multiseriate ray arrangement. 3, TLS showing the uniseriate rays between the multiseriate rays. 4, RLS showing the poor preservation of the rays but some cellular detail visible. 5, Better preserved rays with procumbent and upright cells, and simple perforation plate (RLS) (arrow) visible. 
Localities. Near the village of Beypazarı-Nuhhoca (Kıraluç Site) (KIR) and in the Beypazarı-Mençeler Valley (MEN).

Description. This description is based on three pieces of in situ material measuring $9-13 \mathrm{~cm}$ in length by $5-7 \mathrm{~cm}$ in diameter.

Transverse section (TS). Wood diffuse porous, sometimes semi-ring porous. Growth rings measure 1-11 $\mathrm{mm}$ wide with distinct or indistinct growth ring boundaries. Vessels solitary or in short radial files of 2-4, elliptic or angular when grouped. Vessel tangential and radial diameters measure 62 (20-165) $\mu \mathrm{m}$ and $75(17-193) \mu \mathrm{m}$, respectively. Vessel density is $158(81-252)$ per $\mathrm{mm}^{2}$ (Figure 15).

Tangential longitudinal section (TLS). Rays exclusively uniseriate, very rarely partly biseriate. Rays $272(51-994) \mu \mathrm{m}$ in height and 10 (4-23) $\mu \mathrm{m}$ in width, with $\geq 12$ rays per $\mathrm{mm}$ (Figure 15 ).

Radial longitudinal section (RLS). Rays appear heterocellular with procumbent body ray cells and one to two upright and/or square marginal cells. Intervessel pits are alternate and loosely opposite. Perforation plates simple (Figure 15).

Comments. Salix L. wood can often be confused with that of Populus L., however, the clearly heterocellular rays in this silicified wood identifies this specimen as Salix and has therefore been assigned to Salix sp. Today Salix L. is represented by 33 species in Turkey favouring riparian environments.

Both Salix L. and Populus L. leaves and pollen have been described from GVP (Kasaplıgil, 1977; Denk et al., 2017b) and Salix/Populus wood has been identified from the Hoçaş site (Akkemik et al., 2016). These genera were also common in the Miocene across western Anatolia (Güner, 2016), and support the evidence for the presence of a localized riparian type vegetation occupying lacustrine environments (Toprak et al., 1996 and references cited therein) on the GVP.

Family SAPINDACEAE Jussieu, 1789

Genus ACER Linnaeus, 1753

Acer sp.

Material. INL02, INL06, KIR02, KIR13, KIR51, KIR52 and MEN29.

Localities. Valleys of Beypazarı-Inozu (north side) (INL) and Beypazarı-Mençeler (MEN), and near the village of Beypazarı-Nuhhoca (Kıraluç Site) (KIR).

Description. The following description is based on all seven pieces of ex-situ petrified wood samples measuring $6.5-10 \mathrm{~cm}$ in length by $4-9.5 \mathrm{~cm}$ in diameter although the preservation in the samples collected from Beypazarı-Nuhhoca Village (Kıraluç Site) (KIR) is poor.

Transverse section (TS). Wood diffuse-porous. Ring widths $0.4-1.2 \mathrm{~mm}$. Growth ring boundaries distinct and marked by 1-2 rows of marginal axial parenchyma cells. Tangential and radial diameters of vessels measure $55(11-158) \mu \mathrm{m}$ and 66 (14181) $\mu \mathrm{m}$, respectively. Vessels circular and predominantly solitary with radial multiples of 2-4 or more. Vessel density is 206 (92-343) per $\mathrm{mm}^{2}$. Axial parenchyma is both apotracheal diffuse and marginal. In some of the vessels dark deposits can clearly be seen. Fibers are generally thin walled (Figure 16).

Tangential longitudinal section (TLS). Rays are of two distinct sizes: generally, uniseriate, sometimes biseriate, or multiseriate commonly 4-5 seriate. Rays measure $220(18-656) \mu \mathrm{m}$ in height by 25 (4-78) $\mu \mathrm{m}$ in width. Intervessel pitting alternate. Helical thickening commonly present on the walls of vessels (Figure 16).

Radial longitudinal section (RLS). Rays are homocellular and composed entirely of procumbent cells. Helical thickenings can also be seen in radial walls of the wood. Intervessel pitting alternate. Perforation plates simple (Figure 16).

Comments. This combination of wood features suggests that these samples belong to Acer. This genus is relatively common in the Miocene of Anatolia and is represented at five locations across the GVP with fossil wood having being recovered at Hoçaş and Kozyaka (Akkemik et al., 2016). Further micro- and macrofossils of Acer $\mathrm{L}$. have been recovered from Güvem (Kasaplıgil, 1977; Denk et al., 2017b).

Today Acer is represented by 11 species in Turkey with Acer monspessulanum L. being one of the species adapted to the typically xeric conditions of the Mediterranean (Akkemik and Yaman, 2012). Since the wood features of Acer L. species in Turkey are very similar (Yaltırık, 1971) and cannot be distinguished by wood anatomy alone, this material is referred to Acer sp.

\section{Family ULMACEAE Mirbel, 1815 \\ Genus ULMUS Linnaeus, 1753 Ulmus sp.}

Material. KIR14 and KIR65.

Localities. Beypazarı-Nuhhoca Village (Kıraluç Site) (KIR)

Description. These in situ samples range from 7$9 \mathrm{~cm}$ in length by $8-11 \mathrm{~cm}$ in diameter.

Transverse section (TS). Wood ring porous; growth ring boundaries distinct; ring width 1-2 mm. Earlywood vessels are arranged in 2-3 rows, solitary or 

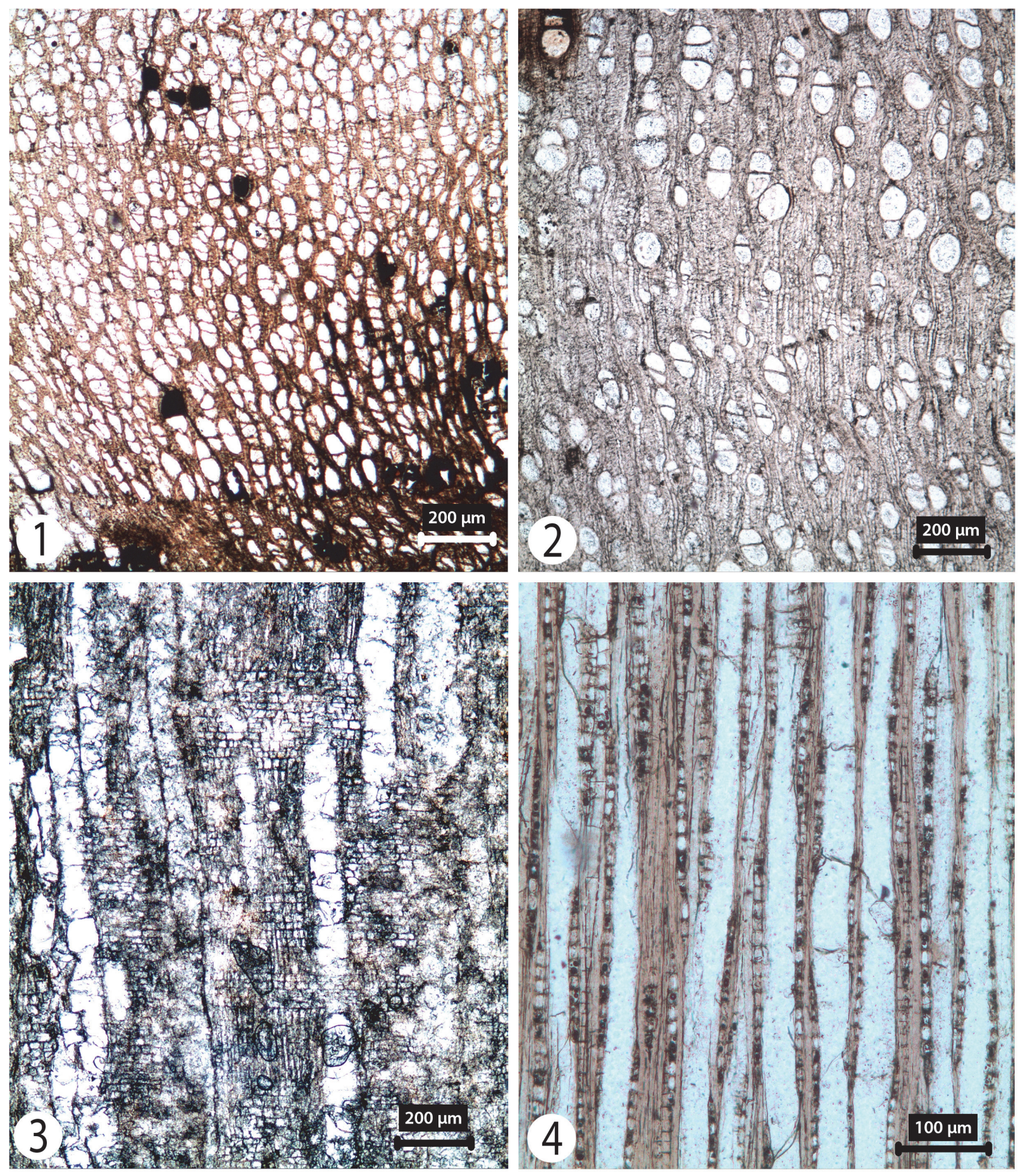

FIGURE 15. Salix. 1, TS showing two growth rings and diffuse porosity of the vessels. 2, TS showing the solitary and paired nature of the vessels. 3, RLS showing ray with both procumbent and upright cells. 4, TLS showing uniseriate rays and vessels.

in radial multiples; latewood vessels arranged in tangential bands. Vessel tangential and radial diameters measure $70(29-117) \mu \mathrm{m}$ and $100(50-$ 169) $\mu \mathrm{m}$, respectively, in the earlywood, and 21 (437) $\mu \mathrm{m}$ and $35(20-46) \mu \mathrm{m}$, respectively, in the latewood. Vessel density is $11(8-14)$ per $\mathrm{mm}^{2}$ in the earlywood and $180(132-244)$ per $\mathrm{mm}^{2}$ in the latewood, overall vessel density is 191 (140-258) 

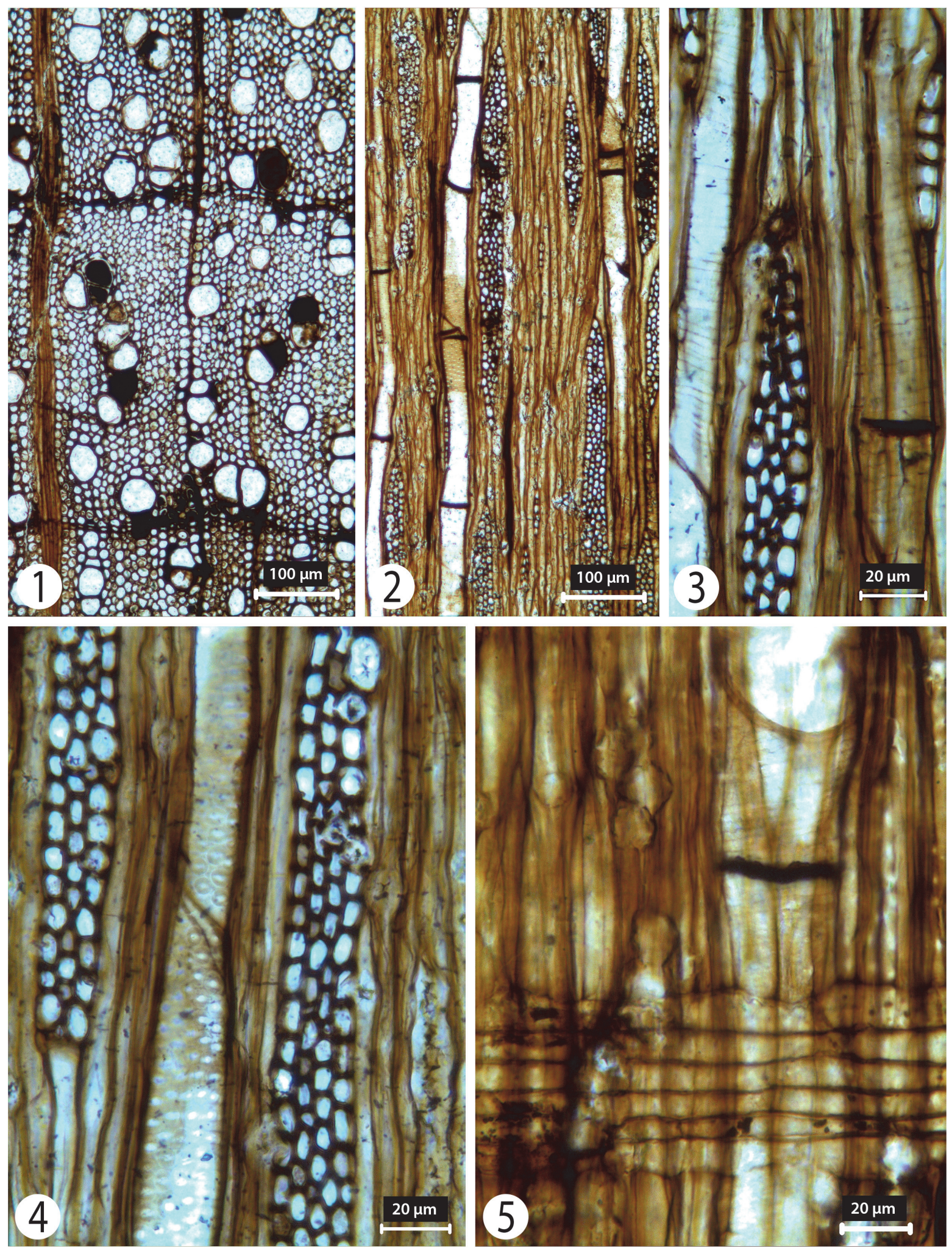

FIGURE 16. Acer. 1, TS showing diffuse porous arrangement of the vessels. 2, TLS showing multiseriate ray arrangement. 3, TLS showing rays of four cells wide and helical thickenings in the vessel wall. 4, RLS showing alternate arrangement of bordered pits on the surface of vessels. 5, RLS showing simple perforation plate and ray with procumbent cells. 
per $\mathrm{mm}^{2}$. Axial parenchyma scanty paratracheal and diffuse (Figure 17).

Tangential longitudinal section (TLS). Rays 3-4 (up to 6) seriate measuring $34(13-63) \mu \mathrm{m}$ in width and 259 (120-445) $\mu \mathrm{m}$ in height (Figure 17).

Radial longitudinal section (RLS). All rays homocellular composed entirely of procumbent ray cells. Intervessel pitting alternate. Perforation plates simple (Figure 17).

Comments. The character combination of these two pieces of petrified woods (i.e., ring porous earlywood vessels, latewood vessels arranged in tangential continuous bands, rays 3-4 (up to 6) seriate, simple perforation plates and homocellular rays) identify this wood as Ulmus $L$.

Today four species of Ulmus are native to Turkey: Ulmus canescens Melville is adapted to xeric conditions within the Mediterranean Basin, the other three species (U. minor Mill., U. glabra Huds. and $U$. laevis Pall.) grow on more humid sites. However, regardless of their ecological preference, the wood anatomy of Ulmus species native to Turkey are all very similar, and it is not possible to separate the species on wood anatomy alone (Akkemik, 1995). Since the wood characters exhibited by the petrified woods studied here are very similar to all four extant species, we refer the fossil material to Ulmus sp.

Other micro and macrofossils of Ulmus have been identified from the Miocene of Turkey, namely woods from the Hoçaş site and the Kıraluç site to the northwest of Beypazarı-Nuhhoca Village (Akkemik et al., 2016), and leaves and pollen from both west Anatolia (Akgün et al., 2007; Akkiraz et al., 2011; Güner, 2016) and at Güvem (Kasaplıgil, 1977; Denk et al., 2017b). This record, therefore, extends the record of Ulmus L. in the local vegetation in this part of Turkey.

\section{Genus ZELKOVA Spach, 1841 Zelkova sp.}

Material. AGU15, AGU28 and KIR01.

Localities. Near the villages of BeypazarıAşağıgüney (AGU) and Beypazarı-Nuhhoca (Kıraluç Site) (KIR).

Description. The following description is based on three pieces of in situ wood measuring $9 \mathrm{~cm}$ in length by $6 \mathrm{~cm}$ in diameter.

Transversal section (TS). Growth rings $0.5-2.5 \mathrm{~mm}$ in width, ring boundaries distinct with transition from earlywood to latewood abrupt. Wood ring porous (Figure 18). Earlywood vessels in 1-2 rows; vessel clusters common in late wood. Vessel tangential and radial diameters measure 76 (23142) $\mu \mathrm{m}$ and 118 (55-182) $\mu \mathrm{m}$, respectively, in the earlywood and $17(6-36) \mu \mathrm{m}$ and 19 (6-42) $\mu \mathrm{m}$, respectively, in the latewood. Vessel density 325 (258-399) per $\mathrm{mm}^{2}$. Axial parenchyma unclear.

Tangential longitudinal section (TLS). Rays 1-6 seriate. Wide rays (3-6 seriate) generally $25-35$ cells, or $379(80-854) \mu \mathrm{m}$, with a maximum height of 51 cells; commonly $>4$ seriate or $41(22-68) \mu \mathrm{m}$; narrow rays (1-2 seriate) $14(6-28) \mu \mathrm{m}$ in width and generally $11-23$ cells or $213(63-482) \mu \mathrm{m}$ in height. Vascular/vasicentric tracheids with helical thickening present (Figure 18).

Radial longitudinal section (RLS). Rays homocellular with entirely procumbent ray cells and heterocellular with mostly procumbent body ray cells and one row of upright and/or square marginal cells (Figure 18). Axial parenchyma in strands of 2-4 cells. Prismatic crystals present in enlarged axial parenchyma cells and in the upright cells of rays. Perforation plates simple.

Comments. The wood of Zelkova Spach. is very similar to that of Ulmus L. but these taxa can be distinguished by the presence of heterocellular rays with one or two rows of upright cells together with procumbent body ray cells and prismatic crystals in the axial parenchyma. These characters can be seen in the fossil wood described here and thus we have assigned this material to Zelkova sp.

The wood identified here is the first record of Zelkova in the fossil wood record of Turkey, although leaf fossils have been identified from both Güvem (Kasaplıgil, 1977; Denk et al., 2017b) and west Anatolia (Güner, 2016; Bouchal et al., 2016, 2017), and pollen has been identified from west Anatolia (Üçbaş Durak and Akkiraz, 2016) and central Anatolia (Akkiraz et al., 2011). Today Zelkova is represented by one species, Zelkova carpinifolia (Pall.) K. Koch., in the flora of Turkey.

\section{DISCUSSION}

\section{Forest Associations Across the Galatian Volcanic Province}

During the early Miocene the climate in western Eurasia was mild and equable, (Rögl, 1999) supporting the growth of rich forest vegetation in Northern Hemisphere as far north as the subarctic (Mai, 1995; Zachos et al., 2008; Denk et al., 2011, 2017a, 2017b, 2017c). Anatolia, along with the Lower Caucasus to the east, formed an island to the north of the eastern Mediterranean and to the south of the Eastern Paratethys (Popov et al., 2004). The Western Pontides Mountains to the north and the Taurus Mountains to the south surrounded the freshwater lakes and marshes that 

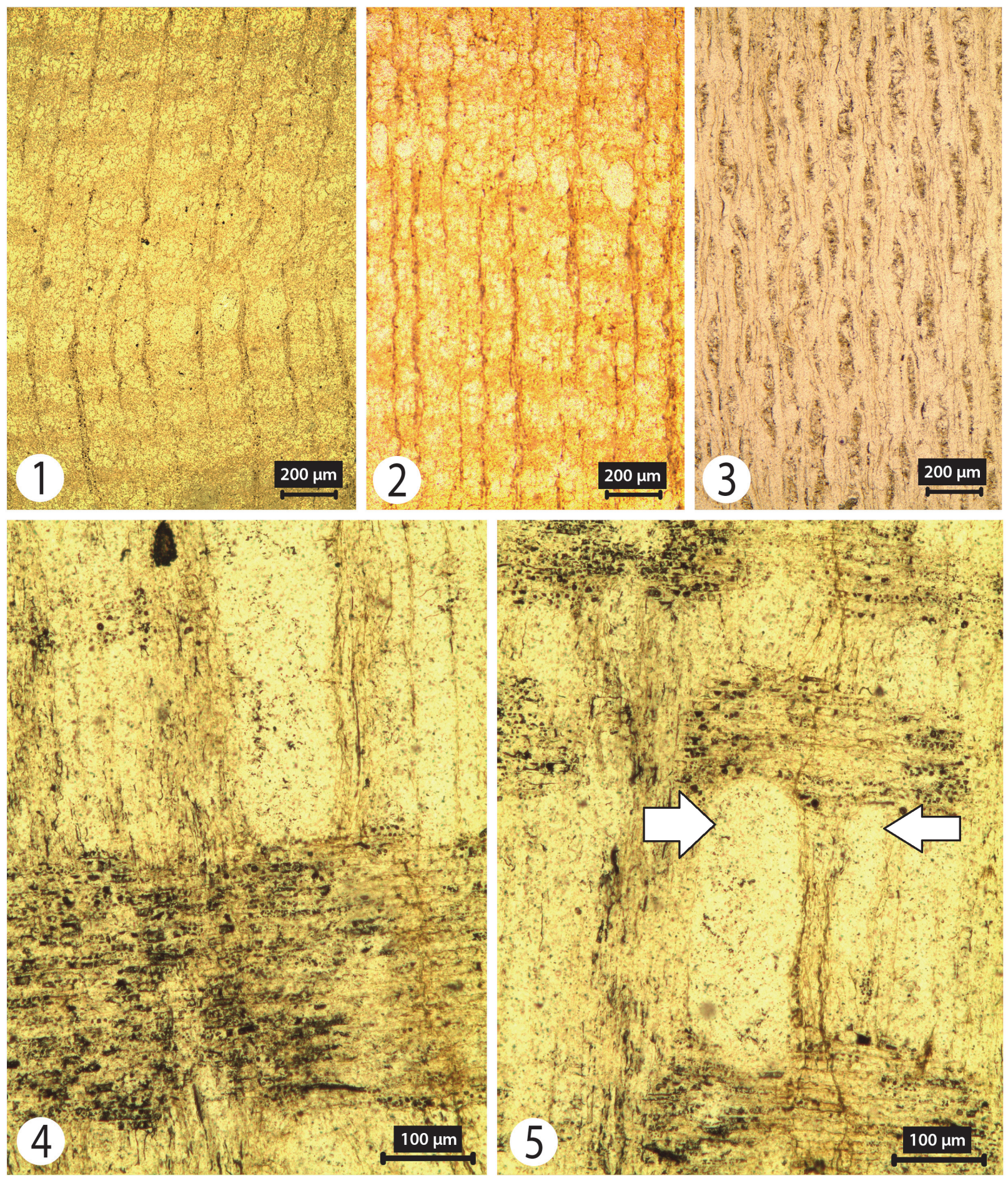

FIGURE 17. Ulmus with poor anatomical preservation. 1-2, TS showing ring porous nature of the earlywood (2) and wavy bands of vessels forming more or less tangential rows in the latewood (1). 3, TLS showing rays of up to 4-5 cells in width. 4, RLS showing rays with procumbent ray cells. 5, RLS showing simple perforation plates (arrows). 

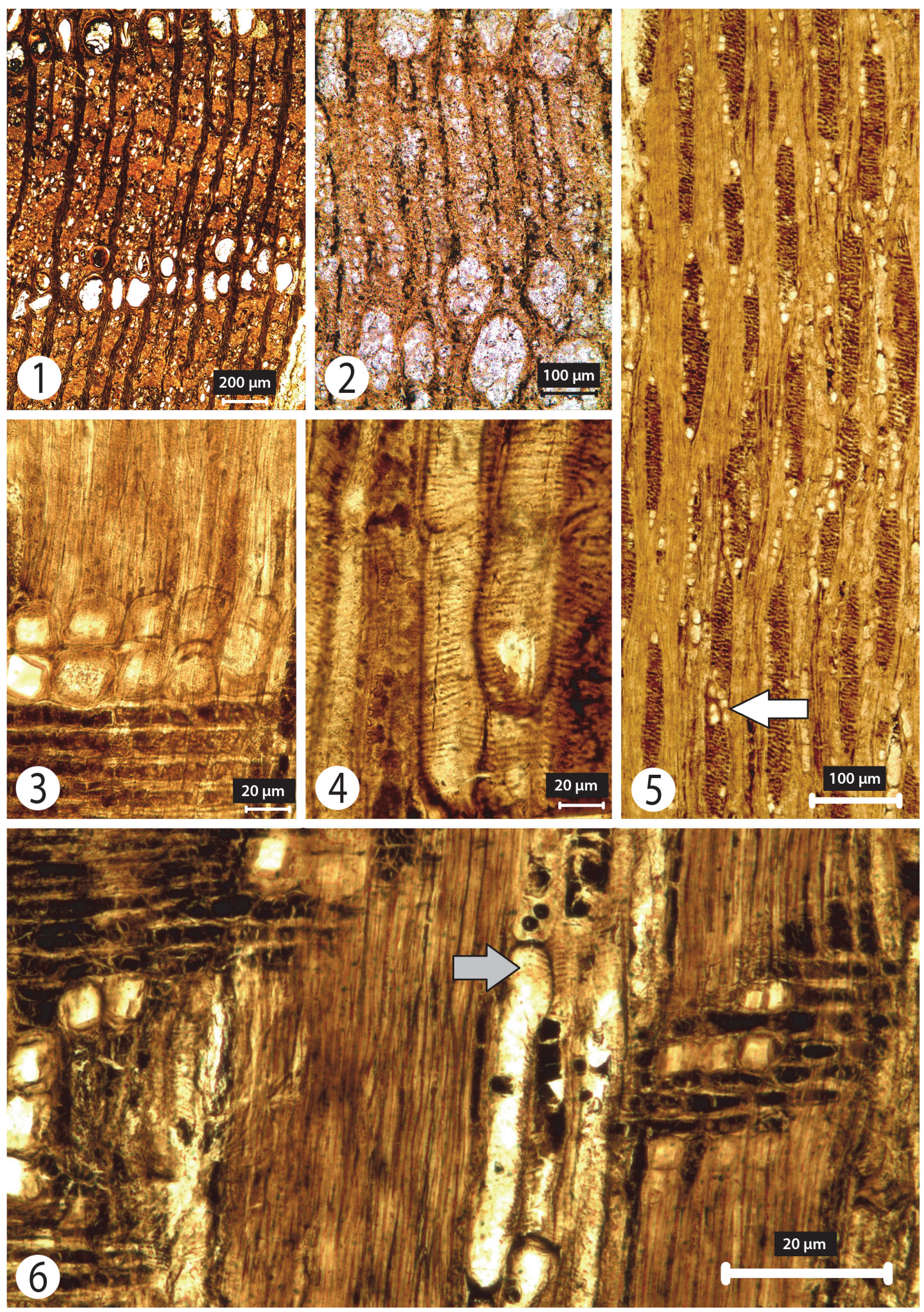

FIGURE 18. Zelkova. 1, TS showing the ring porous nature of the wood. 2, TS showing the vessel arrangement. 3 , RLS of crystals in outer two rows of marginal ray cells. 4, RLS showing vessels having obvious helical thickening. $\mathbf{5}$, TLS showing rays up to 6 cells width and with crystals in their marginal cells (white arrow). 6 , RLS of rays with procumbent ray cells and one row of upright marginal cells, simple perforation plates (grey arrow) in vessels and crystals. 
covered much of the Central Anatolian Plateau (Popov et al., 2004; Schildgen et al 2012a, 2012b). The GVP forms a region in the north-western part of this Central Anatolian Plateau. According to Tankut et al. (1998), the major phase of volcanic activity on the GVP at this time resulted in the deposition of the plant-bearing strata.

Modern analogue techniques (e.g., Utescher et al., 2007; Mustoe and Leopold, 2014) use the composition of floral assemblages present today and compare them with Cenozoic fossil assemblages to provide ecological data of the palaeoenvironments from which the fossils were recovered. Although we do not feel that our palaeoassemblages are complete enough to warrant undertaking such tests just yet, this assemblage approach can provide broad ideas pertaining to the environments in which the trees grew, especially given that these are geologically relatively young assemblages.

The current hypothesis that states the landscape across the GVP were relatively heterogeneous (Denk et al., 2017b) is supported by the results of the local (wood) flora at discrete sites across the GVP found in this study. The 10 sites on the western part of the GVP lie at an altitude of 1000-1400 $\mathrm{m}$ whereas those in the central part of the GVP lie at 1000-1250 $\mathrm{m}$ (Table 1). Since there is no evidence for any significant change in elevation as a result of tectonic processes since the early Miocene, we cannot use altitudinal differences to explain the different vegetation assemblages. Given that the sites located in the western part of the GVP are geographically distinct and possibly slightly younger than those in the western part (Figure 19 and Table 2), we will, however, consider these two regions separately in the context of previously published work.

Forests of the central GVP. Güvem, located in the central part of the GVP, is one of the few precisely dated early Miocene assemblages of plant and animals. The age of this material is $20-18 \mathrm{Ma}$, or early Burdigalian, and many taxa are more typical of temperate and equatorial monsoon climates of SE Asia (van den Hoek Ostende, 2001). Denk et al. (2017b) undertook a major review of the plant material from this area using evidence from leaves, fruits and flower remains and published data of dispersed pollen and spores (Denk et al., 2017a, $2017 \mathrm{c}$ and reference cited therein). A total of 38 of the 40 known taxa identified from the GVP to date have been recorded from Güvem (Table 3). Denk et al. (2017b and reference cited therein) conclude that the landscape was varied and characterized by a mix of trees, shrubs, lianas, ferns and fern allies. Evergreen broadleaved forests comprising Ilex, Quercus and other Fagaceae types dominated the areas surrounding lowland lakes and across large parts of both lowland and uplands (Denk et al., 2017b). Restricted open areas probably supported Fabaceae and Poaceae (Yavuz-Isik, 2008; Denk et al., 2017b). Wetland biomes comprising swamp forest communities and wet meadows surrounded the lakes and rivers where taxodiaceous swamp elements (Glyptostrobus) and palms flourished (Kasapligil, 1977; Denk et al., 2017b). According to Schroeder (1998) and Denk et al. (2017b), the heterogeneous nature of the landscape is further reflected in well-drained lowland broadleaved evergreen forests, mesic mixed deciduous and coniferous upland forests with Sequoia, Fagus types and conifers (Cedrus and Cathaya Chub and Kuang), and the presence of laurel forests. In the pollen flora, a more widespread vegetation assemblage is usually recorded. Yavuz-Işık and Demirci (2009) identified pollen of Pinaceae, Ulmus, Salix, Quercus, Carpinus L., Carya Nutt. and Engelhardia Lesch. ex Blume, which are similar to our findings regarding the composition of the vegetation in the western part of GVP (see below). This suggests that floral associations did indeed vary geographically across this region at this time. These authors also conclude that across the Güvem region the climate was humid and warm temperate, with a somewhat drier season in the winter. This agrees with other studies that suggest the climate in Güvem during the early to mid-Miocene was warm-temperate with a mean annual temperature for the region of $17.2-20.8^{\circ} \mathrm{C}$ (Benda and Muelenkamp, 1990; Akgün et al., 2007; Kayseri and Akgün, 2008; Yavuz-Işık, 2008).

At other sites across the central GVP region, research undertaken on the wood flora has been used to further knowledge of the prevailing local vegetation. In the central region of the GVP to the west of Güvem near Pelitcik, the Camlidere Fossil Forest, dated to 18.2-16.9 Ma, (Tankut et al., 1995 ) is thought to have been composed exclusively of 'Taxodium' and 'Sequoia' (Akkemik et al., 2009); $80 \mathrm{~km}$ to the southeast of Güvem, however, the coeval Güdül Fossil Forest comprised a riparian/wetland environment dominated by a 'Glyptostrobus' forest (Akkemik et al., 2017). Therefore, the wood flora adds support to the idea of local wet biome floral associations postulated by Kasapligil (1977) and later Denk et al. (2017b).

Such swamp forest elements were once widespread across the Northern Hemisphere. Today 
The forest trees in the western side of GVP Early-middle Burdigalian $18-20 \mathrm{Ma}$

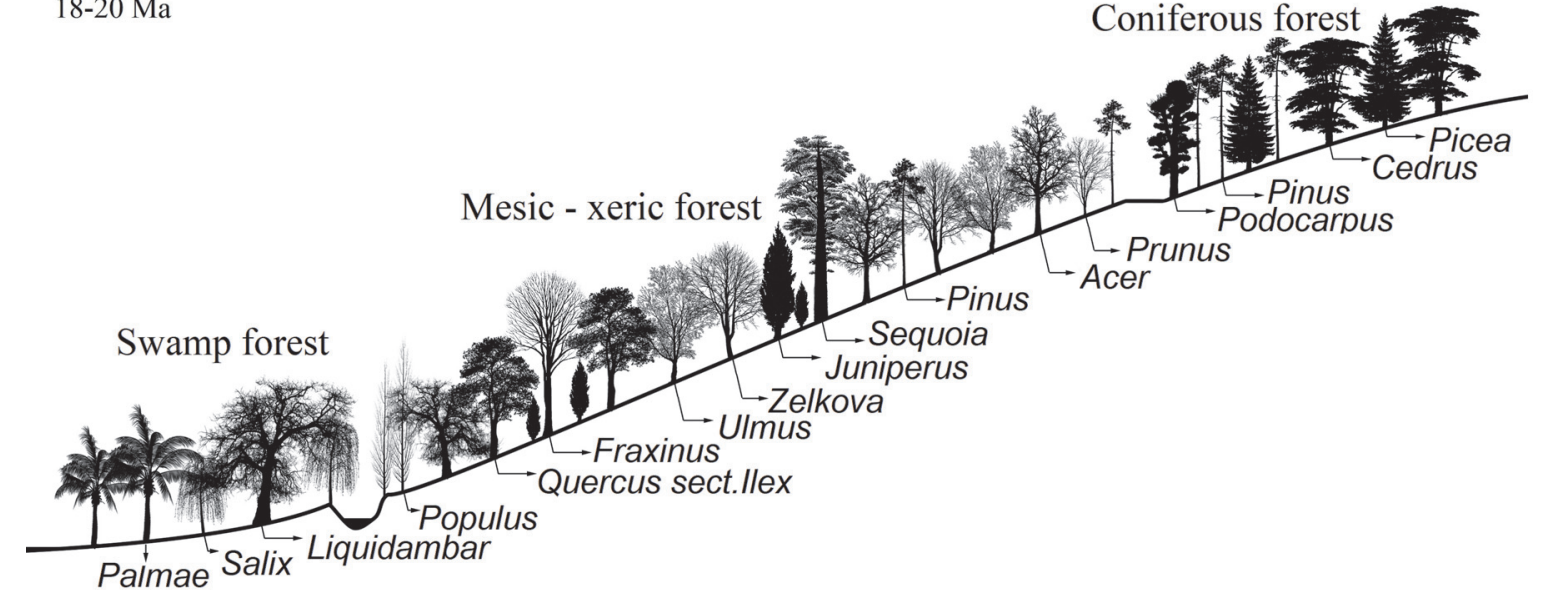

The forest trees in the central part of GVP Middle-late Burdigalian 17-18 Ma

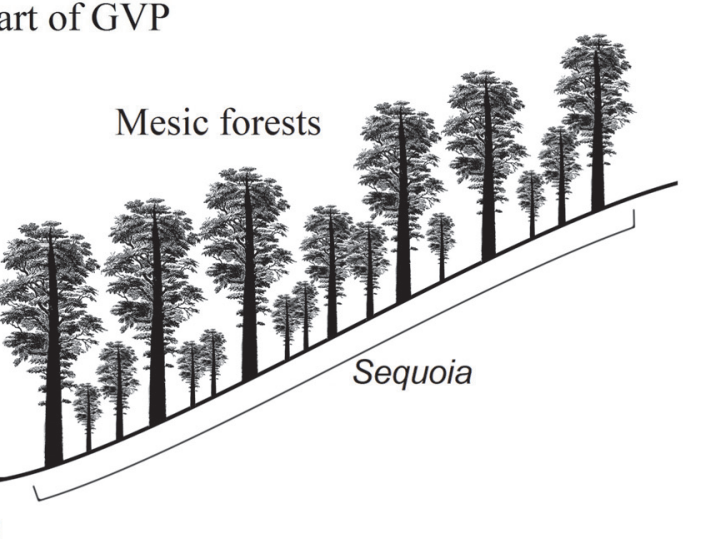

FIGURE 19. 1-2, Summary reconstruction of the two distinct vegetational groups. The elevation line shows possible elevation. The riparian forest vegetation growing on the western side of the GVP at 20-18 Ma based on trees identified from the eight distinct localities (1). Compare this with (2) which summarizes the composition of the more or less contemporaneous swamp forest vegetation (18-17 Ma) growing across the central part of the GVP. (Note that 'Sequoia' type wood can include one or more of Sequoia, Sequoiadendron and Metasequoia).

they are no longer found in Europe or the Mediterranean, but are restricted to the south-eastern USA and parts of East Asia (Mustoe and Leopold, 2014). Taxodium flourishes in regions characterized by poorly drained environments, mild winters, year round rainfall and mean annual precipitation levels of $>1000 \mathrm{~mm} / \mathrm{yr}$ (Hoagland et al., 1996). Today Sequoia is restricted to a $725 \mathrm{~km}$ strip along the Pacific Coast of North America in moist sheltered habitats where the climate is mild and frost free, and moisture levels remain relatively high all year (Eckenwalder, 2009). Glyptostrobus grows in pure stands across parts of Asia along swamp margins, on river floodplains and in deltas; the buttress base and pneumatophores evidence its adaptation to seasonal inundation (Eckenwalder, 2009). This association, as also suggested by the local wood flora in the central part of the GVP and the presence of palms (at Güvem), supports the hypothesis that the climate was warm temperate, 
TABLE 2. A summary list of the genera in western and central GVP. The ages and tree compositions in both groups are different.

\begin{tabular}{ll}
\hline \multicolumn{1}{c}{ Site } & \multicolumn{1}{c}{ Genus } \\
\hline Western GVP & \\
KOZ & Salix/Populus, Cedrus, Pinus, Acer, Ulmus, Quercus sect. Ilex \\
HOC & Cedrus, Juniperus, Picea, Acer, Quercus sect. Ilex, Salix/Populus, Liquidambar, Palmae \\
KUZ & Pinus \\
AGU & Juniperus, Picea, Pinus, Fraxinus, Ulmus, Zelkova \\
KIR & Salix/Populus, Picea, Acer, Ulmus, Quercus sect. Ilex, Zelkova \\
MEN & Salix/Populus, Pinus, Acer, Prunus, Quercus sect. Ilex, Zelkova \\
KAR & Quercus sect. Ilex \\
INL & Cedrus, Acer, Quercus sect. Ilex \\
INO & Cedrus, Sequoia \\
All Western & Cedrus, Juniperus, Picea, Pinus, Sequoia, Acer, Quercus sect. Ilex, Salix/Populus, \\
GVP & Liquidambar, Palmae, Prunus, Ulmus, Zelkova \\
Central GVP & \\
PEL & Sequoia, Taxodium \\
BUG & Sequoia, Taxodium \\
GUD & Glyptostrobus \\
SOG & Sequoia \\
All Central & Glyptostrobus, Sequoia, Taxodium \\
GVP &
\end{tabular}

mild and frost free, during the Burdigalian, and wet habitats existed across the region. Cooling of the climate during the later Miocene (Benda and Muelenkamp, 1990; Kayseri and Akgün, 2008; Yavuz-Işık, 2008) probably caused this swamp-forest association to ultimately disappear from the GVP.

Forests of western GVP. Fossil evidence for the vegetation across the western part of the GVP during the Burdigalian is more limited relative to the central region (Figure 19 and Table 2). Here fossil wood floras of Aquitanian-Burdigalian age are currently the main source of evidence and provide insights into the local, rather than a more regional, vegetation composition. Material from two sites in the very western edge of the GVP have already been studied: The Hoçaş Fossil Forest and the Kozyaka Fossil Forest close to the town of Seben. Wood from the Hoçaş site, dated to between 20 and $18 \mathrm{Ma}$ (Burdigalian) (Akgün et al., 2002; Kayseri and Akgün, 2008; Yavuz-Işık, 2008; Akkemik et al., 2016), comprises palms, conifers (Cedrus, Picea, Juniperus,) and angiosperms (Salix/PopuIus, Acer, Quercus section Ilex and Liquidambar) and represents the most diverse local flora in this region with nine of a possible 40 taxa identified from the GVP. The Kozyaka Fossil Forest (considered to be coeval with the Hocas Fossil Forest; Akkemik et al., 2016) comprises a similar mixed flora of six taxa, namely the conifers Cedrus and Pinus, and the angiosperms Salix/Populus, Acer, evergreen Quercus and UImus.

The results of this study also suggest that relative to the central GVP the local flora in the western part of the GVP is more diverse (Table 3). Quercus section Ilex is the most geographically widespread taxon found at six of the nine sites followed closely by Salix/Populus and Acer found at five of the sites; Picea and Cedrus have been found at four; Zelkova, Ulmus, Juniperus, Podocarpus at two sites; Prunus, Liquidambar, Fraxinus, Sequoia and palms each only on one site.

The localities with the most diverse local floras are: The Kıraluç Site at Beypazarı-Nuhhoca Village (KAR) with seven taxa (Pinus, Podocarpus, Acer, Quercus section Ilex, Salix/Populus, Ulmus and Zelkova), Beypazarı-Aşağıgüney (AGU) with six taxa (Juniperus, Picea, Pinus, Fraxinus, Salix/ Populus and Zelkova) and Beypazarı-Mençeler (MEN) with five taxa (Podocarpus, Acer, Prunus, Quercus section Ilex and Salix/Populus). The remaining localities have relatively few taxa identified to date: Beypazarı-Inozu valley (north side) (INL) had Cedrus, Acer and Quercus section Ilex; Beypazarı Inozu valley (south side) (INO) had Cedrus and Sequoia; Beypazarı-Karaşar Village (KAR) and Bolu-Kıbrısçık-Kuzca-Alanhümmet villages 
TABLE 3. Taxonomic composition of the vegetation that grew across GVP during the early to middle Miocene. See Figure 1 for the site abbreviations and the site names. Data sources are: 1, Akkemik et al. (2016); 2, Akkemik et al. (2017); 3, Akkemik et al. (2009); 4, Kasaplıgil (1977); 5, Denk et al. (2017b); 6, Karayiğit et al. (1999); and 7, Yavuz-Işık (2008).

\begin{tabular}{|c|c|c|c|c|c|c|c|c|c|c|c|c|c|c|c|}
\hline \multirow{3}{*}{ Area } & \multicolumn{9}{|c|}{$\begin{array}{c}\text { Western part of GVP } \\
\text { (Aquitanian-Burdigalian: 24.8-18 Ma) } \\
\end{array}$} & \multicolumn{6}{|c|}{$\begin{array}{c}\text { Central part of GVP } \\
\text { (middle to late Burdigalian: 18.2-16.9 Ma) }\end{array}$} \\
\hline & \multicolumn{2}{|c|}{ 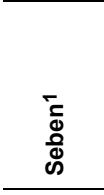 } & \multicolumn{2}{|c|}{ 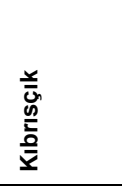 } & \multicolumn{4}{|c|}{ 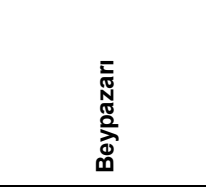 } & \multirow[b]{2}{*}{$\stackrel{*}{\underline{O}}$} & \multirow{2}{*}{ 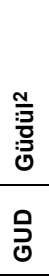 } & \multirow{2}{*}{ 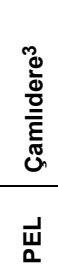 } & \multicolumn{2}{|c|}{ 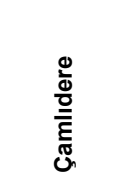 } & \multirow{2}{*}{ 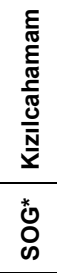 } & \multirow{2}{*}{$\begin{array}{c}\text { Kızılcahamam } \\
4,5,6,7 \\
\\
\text { Güvem } \\
\text { (Pollen and macrofossils) }\end{array}$} \\
\hline & $\underset{\text { No }}{\underline{x}}$ & 옴 & $\stackrel{*}{\stackrel{*}{2}}$ & 㤀 & $\stackrel{*}{\frac{\alpha}{\underline{\alpha}}}$ & 䓵 & $\sum_{\Sigma}^{*}$ & $\stackrel{*}{\underline{z}}$ & & & & 心 & $\sum_{\vec{W}}^{*}$ & & \\
\hline \multicolumn{16}{|l|}{ Gymnosperms } \\
\hline Calocedrus & - & - & - & - & - & - & - & - & - & - & - & - & - & - & + \\
\hline Cathaya & - & - & - & - & - & - & - & - & - & - & - & - & - & - & + \\
\hline Cedrus & + & + & - & - & - & - & - & + & + & - & - & - & - & - & + \\
\hline Glyptostrobus & - & - & - & - & - & - & - & - & - & + & - & - & - & - & + \\
\hline Juniperus & - & + & - & + & - & - & - & - & - & - & - & - & - & - & - \\
\hline Picea & - & + & - & + & - & - & - & - & - & - & - & - & - & - & + \\
\hline Pinus & + & - & + & + & + & - & - & - & - & - & - & - & - & - & + \\
\hline Podocarpus & - & - & - & - & + & - & + & - & - & - & - & - & - & - & - \\
\hline Sequoia & - & - & - & - & - & - & - & - & + & - & + & + & - & + & + \\
\hline Taxodium & - & - & - & - & - & - & - & - & - & - & + & + & - & - & - \\
\hline \multicolumn{16}{|l|}{ Angiosperms } \\
\hline Acer & + & + & - & - & + & - & + & + & - & - & - & - & - & - & + \\
\hline Ailanthus & - & - & - & - & - & - & - & - & - & - & - & - & - & - & + \\
\hline Alnus & - & - & - & - & - & - & - & - & - & - & - & - & - & - & + \\
\hline Berberis & - & - & - & - & - & - & - & - & - & - & - & - & - & - & + \\
\hline Betula & - & - & - & - & - & - & - & - & - & - & - & - & - & - & + \\
\hline Carpinus & - & - & - & - & - & - & - & - & - & - & - & - & - & - & + \\
\hline Carya & - & - & - & - & - & - & - & - & - & - & - & - & - & - & + \\
\hline Castanea & - & - & - & - & - & - & - & - & - & - & - & - & - & - & + \\
\hline Castanopsis & - & - & - & - & - & - & - & - & - & - & - & - & - & - & + \\
\hline Celtis & - & - & - & - & - & - & - & - & - & - & - & - & - & - & + \\
\hline Engelhardia & - & - & - & - & - & - & - & - & - & - & - & - & - & - & + \\
\hline Fagus & - & - & - & - & - & - & - & - & - & - & - & - & - & - & + \\
\hline Fraxinus & - & - & - & + & - & - & - & - & - & - & - & - & - & - & + \\
\hline Ilex & - & - & - & - & - & - & - & - & - & - & - & - & - & - & + \\
\hline Juglans & - & - & - & - & - & - & - & - & - & - & - & - & - & - & + \\
\hline Laurus & - & - & - & - & - & - & - & - & - & - & - & - & - & - & + \\
\hline Liquidambar & - & + & - & - & - & - & - & - & - & - & - & - & - & - & + \\
\hline Magnolia & - & - & - & - & - & - & - & - & - & - & - & - & - & - & + \\
\hline Mahonia & - & - & - & - & - & - & - & - & - & - & - & - & - & - & + \\
\hline Myrica & - & - & - & - & - & - & - & - & - & - & - & - & - & - & + \\
\hline Palmae & - & + & - & - & - & - & - & - & - & - & - & - & - & - & + \\
\hline Platanus & - & - & - & - & - & - & - & & - & - & - & - & - & - & + \\
\hline Pterocaria & - & - & - & - & - & - & - & - & - & - & - & - & - & - & + \\
\hline Prunus & - & - & - & - & - & - & + & - & - & - & - & - & - & - & + \\
\hline
\end{tabular}


TABLE 3 (continued).

\begin{tabular}{|c|c|c|c|c|c|c|c|c|c|c|c|c|c|c|c|}
\hline \multirow{3}{*}{ Area } & \multicolumn{9}{|c|}{$\begin{array}{c}\text { Western part of GVP } \\
\text { (Aquitanian-Burdigalian: } 24.8-18 \mathrm{Ma} \text { ) }\end{array}$} & \multicolumn{6}{|c|}{$\begin{array}{l}\text { Central part of GVP } \\
\text { (middle to late Burdigalian: } 18.2-16.9 \mathrm{Ma} \text { ) }\end{array}$} \\
\hline & \multicolumn{2}{|c|}{ 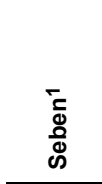 } & \multicolumn{2}{|c|}{$\begin{array}{l}\text { 弟 } \\
\underline{\underline{n}} \\
\underline{\underline{z}}\end{array}$} & \multicolumn{5}{|c|}{ 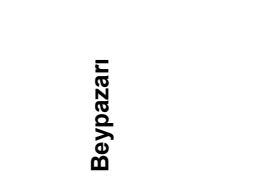 } & \multirow{2}{*}{ 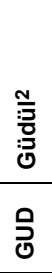 } & \multirow{2}{*}{ 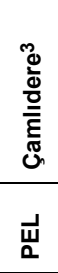 } & \multicolumn{2}{|c|}{ 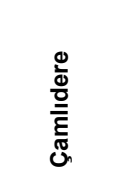 } & \multirow{2}{*}{ 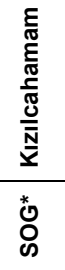 } & \multirow{2}{*}{$\begin{array}{c}\text { Kızılcahamam } \\
4,5,6,7 \\
\\
\text { Güvem } \\
\text { (Pollen and macrofossils) }\end{array}$} \\
\hline & $\begin{array}{l}N \\
\stackrel{2}{2}\end{array}$ & 옴 & $\stackrel{*}{\vec{z}}$ & 管 & $\stackrel{*}{\underline{\alpha}}$ & 帝 & $\sum_{\sum}^{*}$ & $\stackrel{*}{\underline{z}}$ & $\stackrel{*}{\underline{0}}$ & & & $\stackrel{*}{0}$ & $\sum_{\tilde{W}}^{*}$ & & \\
\hline Quercus (section llex) & + & + & - & - & + & + & + & + & - & - & - & - & - & - & + \\
\hline Quercus (deciduous) & - & - & - & - & - & - & - & - & - & - & - & - & - & - & + \\
\hline Salix/Populus & + & + & - & + & + & - & + & - & - & - & - & - & - & - & + \\
\hline Sorbus & - & - & - & - & - & - & - & - & - & - & - & - & - & - & + \\
\hline Tilia & - & - & - & - & - & - & - & - & - & - & - & - & - & - & + \\
\hline Ulmus & + & - & - & - & + & - & - & - & - & - & - & - & - & - & + \\
\hline Zelkova & - & - & - & + & + & - & - & - & - & - & - & - & - & - & + \\
\hline
\end{tabular}

(KUZ) with only one taxon-Quercus section Ilex and Pinus respectively (Figure 19, Tables 2 and 3).

Once again, modern analogue techniques (Utescher et al., 2007; Mustoe and Leopold, 2014) can provide useful information regarding the paleoecology of the western part of the GVP during the Aquitanian-Burdigalian. From comparisons of the assemblages of wood material identified at the sites in the western part of the GVP with the extant flora that grows along the southwestern coasts of Turkey today, we suggest a possible three different forest types may have grown in this region.

A 'riparian forest' association. Today this riparian association is fairly widespread along water courses and includes elements such as Salix, Liquidambar, Alnus, Fraxinus, Ulmus, Platanus, Myrtus, growing together with palms (Phoenix theophrastii Greuter), Juniperus and Pinus (Efe, 1987). Since this association is restricted to water courses it is relatively intolerant of local conditions and can grow in wet, semi-dry and dry environments. This taxa combination has been identified from the HOC site along with Acer, Picea and Cedrus suggesting that the fossil 'riparian forest' flora may have been more taxonomically diverse than its modern counterpart.

A 'mesic-xeric' woodland association. Today in the Mediterranean region of Turkey, under a warm temperate climate with mean annual rainfall of $c$. 500-1000 mm/yr, a semi-dry mesic-xeric macchietype association (Özalp, 2000) is commonly found growing around the extant riparian forest belt at relatively low altitudes (200-1000 m). For example, in south-western Turkey, species of Acer grow alongside several species of evergreen Quercus evergreen oaks (Quercus ilex L., Q. coccifera L. and Q. aucheri Jaub. and Spach) and deciduous oak species in xeric habitats of the Mediterranean region with Pinus and Juniperus (Yaltırık, 1971; Günal, 2011). During the early Miocene, evidence for Acer and Quercus can be found together in five of the nine sites in this part of the GVP (Table 3), sometimes with Pinus and one or more other species not found in the modern analogue. With more studies of these floras, the composition of this vegetational association and the degree of similarity to modern mesic-xeric woodlands will become clearer.

Upland mixed coniferous-angiosperm forest association. Today a conifer association comprising Pinus, Cedrus, Juniperus and Abies can be found at higher altitudes (1000-1800 m a.s.l.) (Yaltırık and Akkemik, 2012). These taxa, except Abies, are present in the fossil assemblages (e.g., KOZ, $\mathrm{HOC}, \mathrm{KUZ}$ ) and might suggest a more upland forest association of this type grew, together with Picea, Podocarpus, Cedrus, during the early Miocene. These conifer elements probably occurred alongside angiosperms (e.g., Acer, Quercus, Salix/ Populus, Ulmus, and possibly Fraxinus and Zelkova). A link to this extant vegetation is certainly more tenuous at this stage, but the possibility does exist that drier habitats of the surrounding higher ground could have supported a more mixed conifer vegetation. Further work is needed to understand more fully the associations these taxa may have had across the GVP at this time. 
The presence of Sequoia at the INO site probably reflects a habitat distinct from this association and more similar to the swamp forests in the central part of the GVP. However, the presence of Cedrus, more commonly found at higher altitudes today, alongside Sequoia may suggest a more diverse habitat and/or vegetation during the Miocene.

Taxodium and Podocarpus are not represented in the floristically diverse assemblage found at Güvem and constitute new records for the GVP. From nearest living relative studies Taxodium would also support a warm temperate environment with humid/damp growing conditions.

Paleoclimate studies undertaken by various workers suggest that a subtropical to warm-temperate climate prevailed over large parts of western Turkey (Güner, 2016), north-western central Anatolia and into Greece during the early Miocene (Velitzelos et al., 2014). The climate was characterized by mean annual temperature of $17.2-21.3^{\circ} \mathrm{C}$, a cold month mean of $6.2-13.3^{\circ} \mathrm{C}$, a warm month mean of $26.5-27.9^{\circ} \mathrm{C}$ and a mean annual precipitation of c. $1000-1325 \mathrm{~mm} / \mathrm{yr}$ and a driest month precipitation level between 40-60 mm (Akgün et al., 2007; Akkiraz et al., 2011). Although the wood associations currently do not provide us with absolute levels of temperature and precipitation at this stage and simply suggest a prevailing warm temperate climate, our findings are in support of the conclusions of Denk et al. (2017a, 2017b, 2017c) and other workers cited above.

\section{CONCLUSION}

The data from fossil wood found at 10 new fossil sites on the GVP (three localities in the central part and seven in the western part) provide a more detailed view of the vegetation associations that grew across the region during the early Miocene. The wood flora suggested evidence of taxonomically distinct local associations. The results provided further support for the current hypotheses for a warm temperate climate prevailing over a heterogeneous landscape comprising a riverine association, a mesic-xeric woodland association and possibly a mixed coniferous forest in the western part of the GVP and swamp forests associations located towards the central part of the GVP. Although this study brings the total of petrified wood genera to 15 , studies of other macrofossils and pollen data suggest many more genera were present across the wider area of the GVP. More work is, therefore, needed before we can fully understand the degree of variation in the vegetation across the GVP.

\section{ACKNOWLEDGMENTS}

This study was supported by the Research Fund of Istanbul University Project Number: YÖP41738 and 22800.

\section{REFERENCES}

Adıyaman, Ö., Chorowicz, J., Arnaud, O.C., Gündoğdu, M.N., and Gourgaud, A. 2001. Late Cenozoic tectonics and volcanism along the North Anatolian Fault: new structural and geochemical data. Tectonophysics, 338:135-165. https://doi.org/10.1016/S00401951(01)00131-7

Akbaş, B., Sevin, M., and Aksay, A. 2002. [1/100.000 Scale Geological Map of Turkey No. 40 Bolu - H27 Sections of MTA Geological Survey Department]. MTA Geological Survey Department, Ankara, Turkey. [In Turkish]

Akgün, F., Akay, E., and Erdoğan, B. 2002. Tertiary terrestrial to shallow marine deposition in central Anatolia: a palynological approach. Turkish Journal of Earth Sciences, 11:127-160.

Akgün, F., Kayseri, M.S., and Akkiraz, M.S. 2007. Paleoclimatic evolution and vegetational changes during the Late Oligocene-Miocene period in western and central Anatolia (Turkey). Palaeogeography, Palaeoclimatology, Palaeoecology, 253:56-90. https://doi.org/10.1016/ j.palaeo.2007.03.034

Akkemik, Ü. 1995. The morphological characteristics of native elm (UImus L.) taxa. Review of the Faculty of Forestry, University of Istanbul, 45(A-2):93-115. 